\title{
ECONOMICS
}

\section{ASYMMETRY IN BOOM-BUST SHOCKS: AUSTRALIAN PERFORMANCE WITH OLIGOPOLY}

\author{
by
}

Rod Tyers

Business School

University of Western Australia 


\title{
ASYMMETRY IN BOOM-BUST SHOCKS: AUSTRALIAN PERFORMANCE WITH OLIGOPOLY*
}

\author{
Rod TYERS \\ Business School \\ University of Western Australia, \\ Research School of Economics \\ Australian National University, and \\ Centre for Applied Macroeconomic Analysis (CAMA) \\ Crawford School of Government \\ Australian National University
}

DISCUSSION PAPER 14.23

Key words:

Dutch disease, China boom, regulation, oligopoly, services, price caps, privatisation, general equilibrium, mining, secondary services boom, three speed boom

JEL codes:

C68, D43, D58, F41, F47, L13, L43, L51, L80

Corresponding author:

Rod Tyers

Winthrop Professor of Economics

UWA Business School

M251, Crawley, WA 6009

Australia

rod.tyers@uwa.edu.au

* The research toward this paper is funded via Discovery Grants from the Australian Research Council: DP1094835 Commodity Booms and Busts and DP0557885 Regulation and Economic Performance. Thanks are due for valuable recent discussions to Ken Clements, Peter Dixon, Bob Gregory, Max Corden and Peter Robertson, and to Mark Horridge for suggesting the line of research in this paper. In addition, valuable comments on earlier and related drafts were received from Flavio Menezes and, at ANU and Monash seminars, from Phillipa Dee, Ben Smith, Martin Richardson, William Coleman, Richard Cornes, Yew-Kwang Ng and Janine Dixon. Assistance in the early stages of DP0557885 was provided by Lucy Rees, Pingkun Hsu and Marcin Pracz, and more recently, by Tsun Se Cheong and David Sami. Finally, all technical analysis for the paper is performed using the Gempack modelling software. 


\begin{abstract}
Australia's comparatively small and open economy is subject to boom-bust shocks that centre on its exporting mining and agricultural industries which, in average years, are minor contributors to its GDP. The associated real exchange rate effects, however, have important implications for overall performance and its distribution between traded industries and largely non-traded services, the latter contributing four-fifths of its GDP with much of it dominated by oligopolies. A common inference concerning the recent "China” boom has been that the following bust will be seriously contractionary, indirectly implying symmetry in economic responses. This paper explores this issue using an economy-wide approach that represents oligopoly behaviour and its regulation explicitly. The results show considerable asymmetry, with booms having proportionally larger effects on performance than busts. This is shown to be affected by oligopoly but to have its roots in neoclassical behaviour. Key implications are that busts do not place all boom gains at risk. Tight regulatory control of pure profits raises and better distributes gains during booms but it prevents pure losses or exits during busts and so exacerbates downturns.
\end{abstract}




\section{Introduction}

Much has been written recently about the end of Australia’s recent “China” boom and some of it has suggested very negative outcomes are likely. ${ }^{1}$ Yet, unlike the booms that have been the focus of the Dutch disease literature, which centre on resource discoveries, this boom has stemmed from an improvement in Australia's terms of trade, driven by the global impact of China's resource-hungry expansion. Of course, from it has stemmed a largely foreign funded investment boom and further exploration that has unearthed new resources. But the primary shock has been to the terms of trade, and so the subsequent bust, likewise, features a terms of trade decline. As it turns out, research on terms of trade shocks extends back beyond the Dutch disease literature, ${ }^{2}$ and indeed beyond the neoclassical literature. A key issue is whether we should expect the welfare effects of a positive terms of trade shock to be simply the reverse of those due to an equally scaled negative shock. The neoclassical answer is, in general, in the negative.

Yet there is a dearth of quantitative studies addressing this point for modern economies, and for Australia in particular.

In practice, pure asymmetries have a number of sources. First, and most elementally, when magnitudes are marginal, positive and negative shocks should have opposing effects of equal magnitude. But large shocks encounter indefinite upsides opposed by non-negativity constrained downsides. Second, Australian booms have centred on mining and agriculture, which are small contributors to its GDP in normal years. Boom shocks that are large increase the income and employment contributions by these natural resource based industries. They therefore enlarge them, enhancing upward responses by the economy as a whole. By contrast, bust shocks shrink those industries, diminishing the effects on overall performance. Third, if the large shocks are to the terms of trade, when positive they enlarge the gains to and from the natural resource based industries. If these shocks are negative, however, the larger they are the more likely it is that the pattern of trade specialisation is reversed and gains to traditional import-competing industries can come to dominate.

Asymmetries can also arise out of the irreversibility of shocks and responses. It has been widely understood that boom shocks, in particular, are not fully reversible. ${ }^{3}$ On the positive side, for example, large investment components cause the capital stock to

\footnotetext{
${ }^{1}$ See, for example, Gregory (2011, 2012), Garnaut (2013), Parham (2013), Sheehan and Gregory (2013) and Lim et al. (2014). Garnaut and Lim et al. also address the effects of the US unconventional monetary policy taper, which is also likely negative for investment in Australia.

${ }^{2}$ See Corden and Neary (1982), Corden (1984, 2012) and Cassing and Warr (1985).

${ }^{3}$ This point is recognised by Gregory (2012) and Garnaut (2013).
} 
be larger following the boom than beforehand. Similarly, skilled immigrants, drawn in by the boom, tend to remain afterward, enhancing productivity following the subsequent bust. On the negative side, some generous labour agreements, formed in the rush to take advantage of boom conditions, are costly to unwind afterward. Further, booms are characterised by new firm entries while busts tend to cause costly exits, consolidations or the continuation of large firms on costly government subsidies. Perhaps in association with these irreversibilities, productivity tends to fall during booms and to rise during busts (Parham 2013). Fiscal policy can differ under boom and bust conditions, ${ }^{4}$ and finally, the effect on the terms of trade of China's slowdown may prove to be smaller than that of its earlier acceleration.

This paper focusses on the pure asymmetries in the response of economic performance to boom and bust shocks, setting aside the above list of irreversibilities associated with factor stocks, policy changes and external conditions. It asks how great the differences are between the effects on Australian economic behaviour of a positive boom shock and a negative bust shock of equal magnitudes. In doing so it generalises the neoclassical treatments by drawing on an economic model that includes the little-traded but otherwise dominant service sector, which is prominent in the standard Dutch disease literature, non-homogeneous products, which allow intra-industry trade, saving, investment and an open capital account, to allow for the response of investment flows, and imperfect competition, which captures the changes in oligopoly rents between booms and busts.

The inclusion of service oligopolies recognises that they form an economic bloc that becomes important during commodity booms and busts because booms tend to accompany real appreciations which see rises in services relative to tradable goods prices and busts the reverse (Corden 2012, Tyers and Walker 2014). Oligopoly pricing can exacerbate this pattern as rents rise during booms and fall during busts. Even where oligopolies are subject to price-cap regulation, the relative decline in tradable input costs during booms can raise rents in these industries, which in any case exhibit information asymmetries and the problem of regulatory capture (Menezes 2009, Nepal et al 2014). This behaviour by service oligopolies might therefore be expected to

\footnotetext{
${ }^{4}$ Of course, so also can monetary policy, though Australia's floating exchange rate might be expected to persist during the impending bust, as it did during the boom.
} 
contribute to asymmetry that makes busts less serious than a mere reversal of the boom shocks and to observed differences in productivity as between booms and busts. ${ }^{5}$

A brief review of Dutch disease theory and its application to Australian boom-bust cycles is offered in the section to follow. Section 3 then describes the model used. The analysis of asymmetry in Australian boom-bust cycles is then provided in Section 4. Conclusions are offered in Section 5.

\section{Terms of Trade shocks and Dutch Disease in Theory}

The neoclassical treatment of terms of trade shocks employs the graphical approach of Figure 1. Technology and factor endowments are reflected in a production possibility frontier. In an autarkic economy convex preferences identify a welfare maximising point on that frontier. If the economy is small and it opens to trade there is no change unless the international terms of trade differs from the autarky one. Any difference, positive or negative, yields a gain in welfare. The effects of this on welfare, or collective utility, can be represented as in Figure 2. The larger departures of the international terms of trade from the autarky level the greater is domestic welfare. These are the gains from trade.

Now, if the starting point is the trading economy represented in the second part of Figure 2, the welfare effects of adjustments in the international terms of trade show considerable asymmetry. An improvement in the terms of trade fosters the $X$ sector at the expense of $Y$ and aggregate welfare improves unambiguously. A decline in the terms of trade benefits the $Y$ sector at the expense of $X$ and the effect on welfare is ambiguous, depending on the magnitude of the change. Small shocks cause straightforward welfare reversals but, if the shock is large enough, the gains to the $Y$ sector become dominant.

The literature on Dutch disease effects came much later, building on the generalisation of the neoclassical model to three sectors with the inclusion of non-traded services by Jones (1971) and Krueger (1977). The Corden-Neary (1982) three-sector model has a booming sector $(B)$, a lagging sector $(L)$ and a non-tradeable sector $(N)$. Sectors $B$ and $L$ produce traded goods, with prices determined exogenously in world markets. Output is determined by labour and a sector-specific fixed factor, resources or capital. Labour

\footnotetext{
${ }^{5}$ Thus, inefficient changes in scale efficiency in oligopolies could explain boom-bust differences in measured productivity. This explanation is not mentioned in the recent debate over Australian productivity determinants (Parham 2013, Quiggin 2001, 2006).
} 
is mobile between the three sectors, equalising the wage rate $W$. Fixed factor rents in the three sectors are $R_{B}, R_{L}$, and $R_{N}$. All goods produced are for final consumption. There is an exogenous technological improvement in $B$, due, say, to a rise in capital investment or the discovery of new resources specific to $B$. Two effects are given prominence. First, the higher incomes of the resource owners must be disposed of, creating a spending effect. Assuming a positive marginal propensity to consume for $N$, demand for it rises. ${ }^{6}$ Since traded goods prices are constrained by free trade, the relative price of $N$ rises and so there is a real appreciation. Increased demand for $B$ and $N$ causes the second effect, the resource movement effect, whereby labour market arbitrage requires redistribution in favour of these sectors and against $L$.

The real appreciation requires some explanation. A standard definition of the real exchange rate is that it is the rate at which a representative bundle of home products can be traded with a corresponding foreign bundle. The key variables are the prices of these bundles of both traded and non-traded goods, which are best represented by the home and foreign GDP price levels expressed in a common currency.

$$
e_{R}=\frac{P_{Y}}{\left(\frac{P_{Y}^{*}}{E}\right)}=E \frac{P_{Y}}{P_{Y}^{*}},
$$

where both the real and nominal exchange rates, $e_{R}$ and $E$, are expressed according to the financial convention, so that an appreciation is a rise in value. In the standard threegood model the law of one price is assumed to apply to traded goods (perfect arbitrage across borders). Since a rise in $P_{N}$ is the only source of change in $P_{Y}$, while its weight in the construction of $P_{Y}$ is less than unity, it has the effect of raising the real exchange rate. $^{7}$

The term de-industrialisation is usually applied to the movement of labour away from $L$. The movement of labour from $L$ to $B$ is called direct de-industrialisation, as it lowers output in $L$ without involving the market for $N$ or the real exchange rate. The indirect counterpart of this movement starts with labour being drawn from $N$ to $B$ but the net flow then depends on the resulting excess demand for $N$ this creates and hence the resulting real appreciation. The result is some moderation of the flow to $B$ and some additional flow from $L$, which is referred to as indirect de-industrialisation. While it is

\footnotetext{
${ }^{6}$ See Corden (1984: 361-362) footnotes for explanation of when the spending effect may actually be negative.

${ }^{7}$ Indeed, it was common in the literature stemming from the three sector homogeneous products model to refer to the ratio of the non-traded good price to some measure of traded good prices as the real exchange rate. In that model this was approximately true.
} 
unambiguous that a resource boom leads to a contraction in output in the lagging sector, the overall effect on the non-traded sector is more ambiguous. The spending effect tends to increase output of $N$, whilst the resource movement effect tends to reduce its output. The relative magnitudes are best examined numerically, due to the many contributing factors. $^{8}$

Thus, the generalisation of a small open economy model with two homogeneous products to include a non-traded good offers interactions between the two tradable industries that are complicated by resource flows into and out of the non-traded sector and by the resulting addition of a real exchange rate, which enhances the contrasting effects on the two industries when the economy is subjected to a change in its terms of trade. There is, however, nothing in these additions to alter the pattern in the second part of Figure 2. Negative terms of trade shocks from the viewpoint of the exported product, $B$, are positive from the viewpoint of the import-competing product, $L$. If these are large enough the gains to $L$ can conceivably offset the losses to $B$. Indeed, it will become apparent that this behaviour persists despite the further generalisation of the model to include differentiated products, saving, investment, fixed costs and oligopolistic industries. Before this is demonstrated, the next section describes the structure and calibration of this more general model.

\section{An Oligopoly Model of the Australian Economy}

The model is structured in the spirit of Blanchard and Giavazzi (2003) in that it emphasises oligopoly rents and the effects on these of industry policies. While their treatment of regulation is directed to entry restrictions, here the regulatory armoury extends to privatisation, pricing surveillance and price-cap regulations. Like that of Balistreri and Markusen (2009), the model separates subnational product differentiation from that between home and foreign products and, with generally higher elasticities of substitution between home products than internationally, it yields important relationships between industry policy, the terms of trade and the real exchange rate. The links between foreign ownership, trade policy, domestic market structure and " $\mathrm{x}$ efficiency” (Markusen 2004, Markusen and Stahler 2011) are not directly explored in

\footnotetext{
${ }^{8}$ Many assumptions and measurements influence the overall effect on the non-traded sector, including capital-intensities, the distribution of ownership, marginal propensities to consume, resource mobility, the number of industries within sectors, demand elasticities, immigration and protection (Corden 1984; Corden \& Neary 1982; Gregory 1976). The empirics are examined using a simple numerical version of the Corden-Nearly model by Tyers and Walker (2013), who find evidence for secondary services booms.
} 
this model though efficiency gains from increased lengths of run in the presence of fixed costs are an important behavioural element. Foreign capital can flow into the economy in the long run but there is no endogenous distinction between FDI as greenfield investment or acquisition.

Critically for the results obtained, the oligopoly behaviour is embedded within a multisector general equilibrium structure which offers a complete representation of interindustry flows. Most oligopolistic sectors (heavy manufacturing and network services) have tended to be comparatively little exported and primarily used as domestic intermediate inputs. This means that, while distortionary pricing by oligopolies has modest direct effects (on final product mark-ups) it has very substantial indirect effects (via mark-ups on intermediates) that build on one another economy wide. A key consequence of this is that, when initial mark-ups are large, more competitive pricing yields effects on overall economic activity that are very much greater than the neoclassical gains in allocative efficiency from changes in taxes, tariffs or even the terms of trade. ${ }^{9}$

\subsection{Model structure}

The scope of the model is detailed in Table 1. Firms in all industries are oligopolistic in their product pricing behaviour with the degree of price-setting collusion between them represented by conjectural variations parameters that are set to account for the degree of regulatory surveillance. Each firm bears fixed capital and labour costs, enabling the representation of unrealised economies of scale. In making this representation, it is recognised that some industries are comparatively competitive, generating low pure profits and carrying low fixed costs. This is represented in the model via parameterisation (larger firm numbers and lower fixed costs per firm), rather than distinct behavioural assumptions.

Home products in each industry are differentiated by variety via CES nests and output is Cobb-Douglas in variable factors and intermediate inputs. While firms are oligopolists in their product markets they have no oligopsony power as purchasers of primary

\footnotetext{
${ }^{9}$ For the Australian case, Tyers (2014) shows that, in general equilibrium, widespread distortions due to collusive oligopoly pricing can reduce real GDP by as much as a third in the long run. Large effects from cuts to oligopoly rents stem from the closer association of costs and prices. Since export demand is comparatively elastic, the resulting declines in costs raise the (variable) capital stock and this facilitates expanded export and output volumes. The output changes then yield a further set of efficiency gains, which come from scale effects: longer production runs in the presence of recurrent fixed costs.
} 
factors or intermediate inputs. ${ }^{10}$ A complete system of inter-industry flows is included so as to represent the dependence of tradable industries on inputs from abroad and from the heavy manufacturing and services sectors. The economy modelled is "almost small”, implying that it has no power to influence border prices of its imports but its exports are differentiated from competing products abroad and hence face finite-elastic demand. ${ }^{11}$ Apart from Australia’s comparatively small economic size, the main reason that the "almost small" assumption is so common in national modelling is that countries specialise in their exports far more than they do in their imports. Australia exports mainly resource-based products, in accord with its comparative advantage, but it imports almost everything. It is therefore much less likely to have market power on the import side.

The consumer price index is constructed as a composite Cobb-Douglas-CES index of post-consumption-tax home product and post-tariff import prices, derived from the aggregate household's expenditure function. This formulation of the CPI aids in the analysis of welfare impacts. Because collective utility is also defined as a CobbDouglas combination of the volumes of consumption by generic product, proportional changes in overall economic welfare correspond with those in CPI-deflated GNP. ${ }^{12}$

Government expenditures comprise those directly on goods and services and CPIindexed transfers to households. Expenditure on goods and services is also via nested CES preferences and government revenue stems from a tax system that includes both direct (income) taxes levied separately on labour and capital income and indirect taxes,

\footnotetext{
${ }^{10}$ Imports in each industrial category are seen as homogeneous, differentiated from home products as a group, so that import varietal diversity never changes. Since all home varieties are exported there is no movement on the "extensive margin" of the type that is evident in the models of non-homogeneous export industries by Melitz (2003) and Balistreri et al. (2007).

${ }^{11}$ The effective numeraire is the import product bundle. Consumer and GDP price indices are constructed for real aggregations, following the practice in national modelling since Dixon et al. (1982) and Harris (1984).

${ }^{12}$ When the utility function is Cobb-Douglas in consumption volumes, the expenditure function is CobbDouglas in prices. If the consumer price level, $P^{C}$, is defined as a Cobb-Douglas index of prices, the equivalent variation in income can be expressed in terms of the proportional change in this index. Thus, following any shock, the income equivalent of the resulting changes to income and prices is:
}

$$
\Delta W=Y_{1}-Y_{0}+E V\left(P_{0}^{C}, P_{1}^{C}, Y_{1}\right)=Y_{1}-Y_{0}-Y_{1} \frac{\Delta P^{C}}{P_{1}^{C}},
$$

which can be expressed in proportional change form as:

$$
\frac{\Delta W}{W}=\frac{Y_{1}\left(1-\frac{\Delta P^{C}}{P_{1}^{C}}\right)-Y_{0}}{Y_{0}} \cong \frac{\Delta Y}{Y_{0}}-\frac{\Delta P^{C}}{P_{1}^{C}} .
$$

This is, approximately, the proportional change in real GNP. 
including those on consumption, imports and exports. ${ }^{13}$ A capital goods sector is included which translates investment expenditure into product and service demands, again using a nested CES preference structure. The level of total investment expenditure has Q-like behaviour, being influenced positively by home rates of return on installed capital and negatively by a financing rate obtainable from an open "bond market” in which home and foreign bonds are differentiated. Savings are sourced from the collective household at a constant rate and from corporations at industry-specific rates applying to the magnitudes of after tax accounting profits earned. ${ }^{14}$ Foreign direct investment and official foreign reserve accumulation are both represented, to complete the external financial accounts. ${ }^{15}$

\subsection{Short run macroeconomic behaviour}

Short run model closures fix productive capital use in all industries but allow investment that would affect production in the future. Central is the open economy capital market which is built around the market clearing identity that includes inward and outward private financial flows. Thus:

$$
I\left(r^{c e}, r\right)=S_{D}\left(Y_{D H}, \pi, G\right)+F I_{\text {Inward }}\left(r, r^{*}, \hat{e}_{R}^{e}\right)-F I_{\text {Outward }}\left(r, r^{*}, \hat{e}_{R}^{e}\right),
$$

where $r$ is the home real financing rate (bond yield), $r^{*}$ is the real yield on bonds abroad (the two being differentiated and so offering different yields) and $\hat{e}_{R}^{e}$ is the expected proportional change in the real exchange rate, defined in (1). Total domestic saving is the sum of saving by households, corporations and government:

$S_{D}=S_{H}\left(Y_{D H}\right)+S_{C}(\pi)+(T-G)$, where $Y_{D H}$ is home household disposable income. The household saving rate is assumed fixed, so that $S_{H}=s_{H} Y_{D H}$. Retained earnings, or corporate saving, $S_{C}$, is assumed to remain a fixed proportion of pre-tax accounting profit at rates that are industry specific, calibrated separately for each industry.

The rate $r^{c e}$ is the expected average net rate of return on installed capital, which takes the following form at the industry level:

$$
r_{i}^{c e}=\frac{P_{i}^{Y e} M P_{i}^{K}}{P^{K}}-\delta_{i},
$$

\footnotetext{
${ }^{13}$ Income taxes are approximated by flat rates deduced as the quotient of revenue and the tax base in each case. Capital income tax rates vary by industry in which the income is earned.

${ }^{14}$ For this the Morningstar data is again used to determine the allocation by firms of after tax profits as between dividends and retained earnings.

${ }^{15}$ Hereafter the capital, financial and official sub-accounts of the balance of payments will be referred to as the "capital account".
} 
where $P^{K}$ is the current price of capital goods, $P^{Y e}$ is the product price level expected to prevail upon gestation and $\delta$ is the rate of depreciation. An average of the sectorspecific rates, $r_{i}^{c e}$, is taken that is weighted by value added in each industry to obtain the economy-wide level $r^{c e}$. Investment expenditure, $I$, is then determined by:

$$
I=P^{K} I_{0}\left(\frac{r^{c e}}{r}\right)^{\varepsilon_{V}}
$$

This relationship constrains the investment response to a change in either the rate of return or the financing rate, offering a reduced form representation of either gestation costs or expectations over short run consequences of installation for the rate of return.

In our comparative static analysis inward and outward foreign investment are motivated by changes in the level of an interest parity function that incorporates the difference between the home and foreign real bond yields and real exchange rate expectations. Two relationships are used to allow for reversals of the direction of net flow in response to shocks, differences in policy obstructions as between inward and outward flows and the recognition that outward flows are portfolio management decisions at home while inward flows are decisions abroad. Inward flows take the form:

$$
F I_{\text {Inward }}=a_{I}+b_{I}\left(r-r^{*}+\hat{e}_{R}^{e}\right), \quad b_{I}>0,
$$

Correspondingly, outward flows are:

$$
F I_{\text {Outward }}=a_{o}+b_{o}\left(r-r^{*}+\hat{e}_{R}^{e}\right), \quad b_{o}<0,
$$

where, the more liberal the capital account the larger are the magnitudes of the parameters $b_{I}$ and $b_{o}$.

The capital market clearing identity (2) then determines the home real interest rate and the magnitude of the external financial deficit ( $I_{\text {Outward }}-I_{\text {Inward }}=S_{D}-I$ ). This is then equal in magnitude to the current account surplus $\left[X-M+N\left(r, r^{*}\right)\right.$, where $N$ is net factor income from abroad $\left.{ }^{16}\right]$. The model is essentially Walrasian in that shocks originating in saving and investment, and hence in external flows, cause home (relative to foreign) product prices (and hence the real exchange rate) to adjust sufficiently to clear home markets and preserve the balance of payments.

\footnotetext{
${ }^{16}$ As modelled, $N$ comprises a fixed net private inflow of income from assets abroad and fixed aid to the government, less endogenous repatriated earnings from foreign-owned physical capital.
} 


\subsection{Oligopoly in supply}

Firms in each industry supply differentiated products. They carry product-varietyspecific fixed costs and interact on prices. Cobb-Douglas production drives variable costs so that average variable costs are constant if factor and intermediate product prices do not change but average total cost declines with output. Firms charge a mark-up over average variable cost which they choose strategically. Their capacity to push their price beyond their average variable costs without being undercut by existing competitors then determines the level of any pure profits and, in the long run, the potential for entry by new firms. Excessive entry is possible in the sense of Mankiw and Whinston (1986) when shocks favour profitability but pure profits are constrained by free entry. Production runs contract and average fixed costs rise. The analysis presented here, however, emphasise cases in which the number of firms remain exogenous.

Each firm in industry $i$ is regarded as producing a unique variety of its product and it faces a downward-sloping demand curve with elasticity $\varepsilon_{i}(<0)$. The optimal mark-up is then:

(8) $m_{i}=\frac{p_{i}}{v_{i}}=\frac{1}{1+\frac{1}{\varepsilon_{i}}} \quad \forall i$

where $p_{i}$ is the firm's product price, $v_{i}$ is its average variable cost and $\varepsilon_{i}$ is the elasticity of demand it faces. Firms choose their optimal price by taking account of the price-setting behaviour of other firms. A conjectural variations parameter in industry $i$ is then defined as the influence of any individual firm $k$, on the price of firm $j$ : $\mu_{i}=\partial p_{i j} / \partial p_{i k}$.

These parameters are exogenous, reflecting industry-specific free-rider behaviour and the power of price surveillance by regulatory agencies. The Nash equilibrium case is a non-collusive differentiated Bertrand oligopoly in which each firm chooses its price, taking the prices of all other firms as given. In this case the conjectural variations parameter $\mu$ is zero. When firms behave as a perfect cartel, it has the value unity. This parameter enters the analysis through the varietal demand elasticity.

Critical to the implications of imperfect competition in the model is that the product of each industry has exposure to five different sources of demand. The elasticity of demand faced by firms in industry $i, \varepsilon_{i}$, is therefore dependent on the elasticities of demand in these five markets, as well as the shares of the home product in each. They 
are final demand $(F)$, investment demand $(V)$, intermediate demand $(I)$, export demand $(X)$ and government demand $(G)$. For industry $i$, the elasticity that applies to (8), above, is a composite of the elasticities of all five sources of demand.

$$
\varepsilon_{i}=s_{i}^{F} \varepsilon_{i}^{F}+s_{i}^{V} \varepsilon_{i}^{V}+s_{i}^{I} \varepsilon_{i}^{I}+s_{i}^{X} \varepsilon_{i}^{X}+s_{i}^{G} \varepsilon_{,}^{G} \quad \forall i
$$

where $s_{i}^{j}$ denotes the volume share of the home product in market $i$ for each source of demand $j$. These share parameters are fully endogenous in the model and the elasticities depend on component elasticities of substitution and the conjectural variations parameters $\mu_{i}$.

Thus, the strategic behaviour of firms, and hence the economic cost of oligopolies, is affected by collusive behaviour on the one hand and the composition of the demands faced by firms on the other, both of which act through the average elasticity of varietal demand. The collusive behaviour enters through conjectural variations parameters, $\mu_{i}$, and composition through the demand shares $s_{i}^{j}$. Of course, the capacity firms have to reduce their prices also depends on the fixed cost burden carried by each industry and hence on firm numbers.

To study the effects of price-cap regulation a Ramsey mark-up, $m_{i}^{R}$ is formulated as:

$$
m_{i}^{R}=\frac{a f c_{i}+v_{i}}{v_{i}}
$$

where $a f c_{i}$ is average fixed cost and $v_{i}$ is average variable cost in industry $i$.

Compromise mark-ups can be simulated by altering the parameter $\varphi_{i}$ in an equation for the "chosen" mark-up: $m_{i}^{C}=\left(\varphi_{i}-1\right) m_{i}^{R}+\left(2-\varphi_{i}\right) m_{i} \quad \forall i$. Thus, when $\varphi_{i}=1, m_{i}^{C}=m_{i}$, thus maximising oligopoly profits, and when $\varphi_{i}=2, m_{i}^{C}=m_{i}^{R}$, eliminating pure economic profits altogether.

\subsection{The database and its representation of broad economic structure}

The flow data for the current model originates from the GTAP Version 7 global database for $2007 .{ }^{17}$ It combines detailed bilateral trade, transport and protection data characterizing economic linkages among regions, together with individual country national accounts, government accounts, balance of payments data and input-output tables which enable the quantification of inter-sectoral flows within and between

\footnotetext{
${ }^{17}$ Documentation on the GTAP 6 Data Package may be viewed at: $<\underline{\text { http://www.gtap.agecon.purdue.edu/databases/>. }}$.
} 
regions. Factor shares and input output coefficients from these 2007 data are combined with national accounts and balance of payments data to construct the complete social accounting matrix. Key structural elements are evident from Table 2.

Factor shares of value added in each industry are important in interpreting the results. They are listed in Table 3. These data confirm that capital intensity is highest in mining and network services while intensity in production labour is highest in tradable products, especially agriculture and manufacturing. Intensity in skilled labour is highest in network and other services. These relative intensities drive the distribution of factor rewards from terms of trade shocks, and also their implications for the distribution of output across industries. Boom shocks cause “de-industrialisation” and hence the loss of comparatively labour-intensive production and so their effects differ depending on the labour market closure chosen. Similarly, bust shocks contract capital intensive activity and their effects therefore depend on the international mobility of capital.

\subsection{Calibration of pure profits and oligopoly parameters}

The flows represented in the database do not reveal details of intra-sectoral industrial structure. To represent oligopolistic behaviour, additional information is required on effective firm numbers, pure profits, fixed costs and minimum efficient scale for each industry. With the support of the Morningstar Database on listed firms in Australia these variables are calibrated in the following manner. First, pure profits are required as a share of total revenue in each industry. This is needed to finalise the flow database by splitting capital payments between market and over-market returns. ${ }^{18}$ It is also a starting point for calibrating industry competitive structure. Second, rough estimates are required of strategically interacting firm numbers in each industry and their corresponding conjectural variations parameters. Again, the Morningstar data provide numbers and sizes of listed firms the concentration of which is suggested in Figure 3. Most Australian industries are dominated by a few firms, even if the total numbers are large. It is very likely the bigger firms that most influence prices, as discussed in Appendix 3.

Third, to complete the formulation of industry demand elasticities, values of elasticities of substitution between home product varieties on the one hand, and between generic

\footnotetext{
${ }^{18}$ Pure profit shares of total revenue in 2005 were high in "metals and minerals", "petroleum and energy", "telecommunications", "insurance and finance" and "transport”. Data on accounting profits in the latter three sectors is comparatively weak and the estimates are partly judgemental, accounting for such determinants as low borrowing rates for these SOE dominated sectors and hence low capital service costs. See the appendices to Tyers and Lu (2008).
} 
home and foreign products on the other, are required for each industry. These are initially drawn from the estimation literature. ${ }^{19}$ Preliminary industry demand elasticities are then calculated for each source of demand (final, intermediate, investment, government and export). Initial shares of the demand facing each industry are then drawn from the database to enable the calculation of weighted average demand elasticities for each industry. Preliminary mark-up ratios are deduced from these, via (8). The initial elasticities and mark-up ratios for each industry are listed in Table $4 .^{20}$ This completes the initial demand side calibration. Work on the supply side begins with the application of mark-up ratios to deduce the initial level of average variable cost in each industry. Then the proportion of pure profits in total revenue is deducted from the mark-up to arrive at fixed cost revenue shares. ${ }^{21}$ Total recurrent fixed cost in each industry then follows. At this point these results are reviewed and, where conflicting information is available on fixed cost shares of total turnover, the calibration is recommenced with new initial elasticities. ${ }^{22}$ The initial levels of pure profits, the shares of fixed and variable costs and industry scale are listed in Table 5.

Importantly for the interpretation of later results, the five sources of demand facing firms in each industry are not equally elastic. As detailed in Appendix 3, export and final demand are the most elastic and intermediate demand the least. ${ }^{23}$ It is further evident that, where exports dominate demand firms face larger elasticities and charge smaller mark-ups. Consistent with these observations, pure profit shares of total revenue tend to be smaller for export-oriented industries and larger for the network services.

\subsection{The closures used}

In the experiments to be presented both long and short run closures are used. The details of these are indicated in Table 6. In essence, long run closures have total capital use, and its distribution between industries, endogenous with foreign capital being

\footnotetext{
${ }^{19}$ Summaries of this literature are offered by Dimaranan and McDougall (2002) and at http://www.gtap. purdue.edu/databases/.

${ }^{20}$ These elasticities appear large in magnitude at first glance because they do not represent the slopes of industry demand curves for generic goods. Rather, they are the elasticities faced by suppliers of individual varieties and are made larger by inter-varietal substitution.

${ }^{21}$ Fixed costs take the form of both physical and human capital costs using the rule of thumb (based on estimates by Harris and Cox, 1983) that physical capital has a fixed cost share of 5/6.

${ }^{22}$ The actual calibration process is yet more complex than this because the elasticities of intermediate demand depend on intermediate cost shares, which depend on the variable cost share. It is therefore necessary to calibrate iteratively for consistency of elasticities and shares.

${ }^{23}$ Export demand is found to be more elastic because of the larger number of substitutable product varieties available abroad while intermediate demand is relatively inelastic because of firms' reluctance to alter arrangements for intermediate input supply which may depend on location or "just in time” relationships.
} 
supplied elastically at a common external rate of return. Labour supplies are fixed and wages endogenous. By contrast, short run closures keep total capital use, and its industrial distribution, fixed while allowing production labour use to vary given an exogenous real wage set at its initial level. The fiscal policy closure is the same in all experiments, simply maintaining a constant fiscal surplus throughout. ${ }^{24}$

\section{Asymmetry in Boom-Bust Shocks}

Commencing from the 2007 equilibrium of the Australian economy, terms of trade shocks are applied by raising or lowering the external prices of "agriculture" and "mining-energy". These shocks change both import and export prices, the former directly and the latter by causing substitution abroad toward Australian exports. The aggregation of mining and energy commodities alters the domestic implications of these shocks since mining products are exported while Australia is a net importer of energy products. Although it has been true that mineral and energy commodity prices have cycled similarly the consequence for this analysis is that the decline in the price of this aggregate necessary to bring about “mining-energy” product autarky is smaller than would be required to achieve this for minerals alone. The simulations are organised according to the closures in Table 6. The long run closure is considered first terms of trade shocks ranging between +50 per cent and -50 per cent are applied under the three long run alternatives - unfettered oligopoly ${ }^{25}$, free entry and exit and regulated oligopoly, the latter subject to price caps that force pricing at average total cost. The analysis then turns to the short run, for which there are two alternative sub-closures: unfettered oligopoly and regulated oligopoly.

\section{Long run analysis}

As expected, positive terms of trade shocks yield substantial economic gains, whether measured in terms of welfare (CPI-deflated GNP) or domestic activity (real GDP). Foreign ownership of some Australian capital ensures that the gains in activity are smaller than those in welfare. Accompanying these gains are significant real appreciations, which occur as increased global demand for Australian products raises the cost of its product bundle relative to those abroad. This occurs, in part, via changes

\footnotetext{
${ }^{24}$ Clearly, fiscal policy in Australia has differed as between booms and busts. This fact contributes to irreversibility but not to asymmetry, which is the focus here.

${ }^{25}$ Unfettered oligopoly does not imply cartel behaviour. Conjectural variations parameters remain less than unity and this is intended to suggest coordination costs as well as the effects of regulatory price surveillance.
} 
in the prices on differentiated Australian tradable goods but primarily from the standard Dutch disease effects of the rise in home income on demand for services, discussed in Section 2.

When the terms of trade shocks are reversed, there is striking asymmetry, as shown in Figure 5. That this is driven primarily by the underlying neoclassical effect of shifting the economy toward product autarky in the "mining-energy" aggregate is clear from a comparison of the welfare (CPI-deflated GNP) changes with the welfare effects illustrated in Figure 2. Autarky in this aggregate implies equal export and import values and it occurs with a terms of trade decline of around 15 per cent in the long run. Negative terms of trade shocks larger than this are advantageous, fostering net exports in manufacturing and, on a smaller scale, in some services. Asymmetry in the real exchange rate change occurs because shocks that reduce agriculture and mining-energy prices cause those industries to contract in the long run so their weights in the Australian product bundle decline. The smaller they become the smaller the impact on the relative price of that bundle. ${ }^{26}$

Also strikingly, the effects of differences in oligopoly behaviour are comparatively slight. These effects turn out to be sensitive to the elasticities that underlie industry mark-ups and initial fixed cost shares. Larger trade elasticities, for example, enhance the contrast between the elasticities of export relative to the other demands facing firms, which is modest in the initial database, as indicated in Table $4 .{ }^{27}$ The greater is this contrast, the stronger is the upside relative performance of the regulated oligopoly case and the weaker is its performance on the downside. This is because overall oligopoly rents increase during booms since manufacturing and the network services face more intermediate demand and hence smaller elasticities and this effect is larger than the reduced rents in the booming industries that arise when export shares rise and elasticities fall.

The result is that unfettered oligopoly adds costs during booms but, during busts, it reduces them. Control of the boom costs, both direct and intermediate, fosters demand growth and an expanding capital stock, as indicated in Table 7. On the downside the regulation forces the coverage of all average costs by the fixed number of firms and so contracts demand relative to cases where either those firms can carry pure losses or exit. The capital stock therefore contracts more dramatically in this case. Worst performing

\footnotetext{
${ }^{26}$ Indeed, the real exchange rate effects would be asymptotic at zero for very large negative shocks.

${ }^{27}$ A sensitivity analysis is under construction to support this.
} 
on the upside is the free-entry case. This is because firm numbers rise and so the economy carries higher recurrent fixed costs. On the downside this alternative performs similarly to the unfettered oligopoly case since it offers exits, and so reduced total costs while oligopoly allows adjustment via the carriage of pure losses, or reduced rates of return on capital.

The principal reason for modest oligopoly effects, however, is that terms of trade shocks cause sheer stresses in the economy. Some industries expand while others contract. Industries that become more directed to final and export demand have declining markups while those whose demand shifts toward investment and intermediates have raised mark-ups. This is clear from Table 8, which shows that weighted average mark-up changes are much smaller than the associated changes to industry mark-ups in tradables or in services like transport and the "other services” category. Correspondingly, changes in oligopoly rents (pure profits) in the oligopoly case also wash out across the economy even though they expand in boom-advantaged tradable industries and in other services. The same is true for scale efficiency, which expands in advantaged industries and contracts in others leaving a net tendency toward expansion during booms and contraction during busts. The only exception to this is the free entry case, since firm entry tends to reduce scale.

\section{Short run analysis}

Here the key difference is that capital use is fixed and that labour use is variable. The pattern of the results is very similar to the long run. In particular, it is dominated by the neoclassical effect of proximity to product autarky (equal values of imports and exports) in the mining-energy industry and so the curves in Figure 6 are similar to those in Figure 5, as well as to that in Figure 2. Again the regulated oligopoly case performs best on the upside and worst on the downside, for the same reason as in the long run. It removes oligopoly rents and so controls costs on the upside and, by forcing the full coverage of average total costs, offers higher prices and less demand on the downside than the unfettered oligopoly case in which firms can carry pure losses.

There are two key differences between the long and the short run results, however. First, the magnitudes of the effects on welfare, real economic activity and the real exchange rate are all much larger in the short run. This is because the rigid levels of capital use and the fixed real production wage limit inter-sectoral adjustment to the shocks. Larger trade elasticities would reduce initial mark-ups and the size of the welfare and real activity effects in the short run. 
Second, the asymmetry is now quite extreme. Indeed, the downside no longer sees significant economic contraction. The reason for this lies in the structure of the initial database. It tends not to reflect the expected "secondary services boom” of Corden (2012) and Tyers and Walker (2013). Expenditure shares on the network services are smaller than expected in final (household), investment and government demand, while they are larger than expected in demand derived from manufacturing activity. The initial set of trade elasticities chosen may be on the high side for manufacturing, since it is clear that Australia's modern manufacturers have survived reduced protection and exchange rate volatility by associating themselves closely with secure industries in mining-energy and services. The elasticities used here cause boom shocks to deliver more de-industrialisation than has actually been observed in Australia. In association, since manufacturing is also comparatively intensive in production labour, we see in the boom solutions net contractions in production worker demand as well as in the demand for network services. These contractions are sufficient to outweigh increases in demand for "other services" and the workers it employs. When the terms of trade shocks are negative, however, total employment expands with manufacturing and the network services, more than offsetting contractions in employment in "other services". These idiosyncrasies cut against the employment gains and net immigration that were persistent throughout the China boom, the GFC notwithstanding, and so suggest scope for further work on the model database and its representation of the structure of demand. ${ }^{28}$

\section{Conclusions}

Australia's comparatively small and open economy is subject to boom-bust shocks that centre on its exporting mining and agricultural industries. In average years these are minor contributors to its GDP yet the resulting real exchange rate effects have important implications for overall performance and its distribution between traded industries and largely non-traded services, the latter contributing four-fifths of its GDP with much of it dominated by oligopolies. A common inference concerning the recent “China” boom has been that the following bust will be seriously contractionary, indirectly implying symmetry in economic responses. Here an economy-wide approach is applied that represents oligopoly behaviour and its regulation explicitly. The results show

\footnotetext{
${ }^{28}$ Since preferences are modelled as homothetic, it is possible that the large income shocks associated with the boom, combined with comparative income elasticity of services, cause the model to underrepresent shifts in demand structure.
} 
considerable asymmetry between the effects of boom shocks with equiproportional busts. Booms are shown to have proportionally larger effects on performance than busts. While the scale of the responses to terms of trade shocks in either direction appears to be affected by oligopoly, the observed asymmetry is primarily a consequence of proximity to autarky in traded product markets (import values equalling export values) in a manner that is equivalently evident in the standard neoclassical treatment of trade in two homogeneous goods.

The effects of oligopoly behaviour are to raise rents, and therefore to impair economic performance, during booms and to reduce them, moderating the downside, during busts. These effects are controlled in the experiments by either allowing free entry and exit or regulating pricing by existing firms to ensure that it is sufficient to cover average total costs only. The former approach has the effect of allowing substantial entry during booms and the carrying of the cost of corresponding exits during busts. Moreover, the additional firms all add to the economy's fixed cost burden. The alternative of regulating existing firms, and thereby restricting the pure profits that induce entry, yields better performance during booms because it controls costs transmitted through intermediate demand and it captures scale efficiencies. Keeping all the original firms during busts and continuing to impose the requirement that they price to cover average total costs, diminishes performance relative to unfettered oligopoly with fixed firm numbers, which allows negative pure profits (low rates of return on capital) during busts, or the free entry/exit alternative that allows firm exit or consolidation during busts.

The key implications are that busts following booms do not necessarily place all boom gains at risk. It is further suggested that tight regulatory control of pure profits raises and better distributes gains during booms but it prevents pure losses or exits during busts and so exacerbates downturns. The downside is to be traded off against costly exits or government protection during busts where “excessive” entries are fostered during prior booms.

The work suggests a number of issues for further research. First, the 2006-7 database for the Australian economy appears to lack support for the secondary services boom that sustained employment growth throughout it, notwithstanding the GFC. Elements of the database require checking down to their original sources to identify causality. Second, the construction of the database, and its imperfect competition elements in particular, tends to lock in elasticities of substitution that underlie demand behaviour and industry 
mark-ups, there remains scope to vary these elasticities. While the general pattern of asymmetry found is robust to such changes, the effects of alternative oligopoly assumptions are quite sensitive to these elasticities. This sensitivity deserves further exploration. Finally, the paper addresses pure asymmetry only, ignoring irreversibilities of shocks and some behavioural changes in response to them. A more general treatment of irreversibility is suggested.

\section{References}

Balistreri, E.J., R.H. Hillberry and T.J. Rutherford (2007), "Structural estimation and solution of international trade models with heterogeneous firms", presented at the 10 Annual Conference on Global Economic Analysis, Purdue University, July.

Beaudry, P. and Portier, F. (2007), 'When can changes in expectations cause business cycle fluctuations', Journal of Economic Theory, 135, 458-77.

Cassing, J. and Warr, P. (1985), 'The Distributional Impact of a Resource Boom', Journal of International Economics, 18, 301-319.

Coleman, W. (2008), "Gauging economic performance under changing terms of trade: real gross domestic income or real gross domestic product?” Economic Papers, 27(4), 101-116, December.

Cooper, R.J. and K.R. McLaren (1983), “The ORANI-MACRO interface: an illustrative exposition”, The Economic Record, 59(165): 166-179.

Cooper, R.J., K.R. McLaren and A.A. Powell (1985), "Short-run macroeconomic closure in applied general equilibrium modelling: experience from ORANI and agenda for further research”, in J. Whalley and J. Piggott (eds), New Developments in Applied General Equilibrium, Cambridge University Press: 411-440.

Corden, W.M. (1984), "Booming Sector and Dutch Disease Economics: Survey and Consolidation", Oxford Economic Papers, 36, 359-380.

Corden, W.M. (2012), 'The Dutch Disease in Australia: Policy Options for a ThreeSpeed Economy’, Australian National University, Arndt-Corden Department of Economics, Working Paper 10, Canberra.

Corden, M. and Neary, P. (1982), "Booming sector and de-industrialization in a small open economy”, The Economic Journal, 92: 825-848.

Dimaranan, B.V. and McDougall, R.A., 2002. Global Trade, Assistance and Production: the GTAP 5 data base, May, Center for Global Trade Analysis, Purdue University, Lafayette.

Dixon, P.B., Parmenter, B.R. and J. Sutton (1978), "Some causes of structural maladjustment in the Australian economy”, Economic Papers, January: 10-26.

Dixon, P.B., Parmenter, B.R., Sutton, J. and Vincent, D.P. (1982), ORANI, a MultiSectoral Model of the Australian Economy, North Holland, Amsterdam.

Dixon, P.B. and Rimmer, M.T. (2002), Dynamic General Equilibrium Modelling for Forecasting and Policy: a Practical Guide and Documentation of MONASH, Contributions to Economic Analysis 256, North-Holland Publishing Company; xiv-338. 
Dixon, P.B. and Rimmer, M.T. (2004), “The US economy from 1992 to 1998: results from a detailed CGE model”, Economic Record, 80 (Special Issue), September, S13-S23.

Freebairn, J. (2012), “Mining booms and government budgets”, The Australian Journal of Agricultural and Resource Economics, 56: 201-221.

Freebairn, J. and J. Quiggin (2010), "Special taxation of the mining industry," Economic Papers, 29(4): 384-396, December.

Garnaut, R. (2012), “The contemporary China resources boom”, The Australian Journal of Agricultural and Resource Economics, 56: 223-243.

(2013), Dog Days: Australia after the boom, Melbourne Australia: Black Inc. Redback.

Gregory, R. (1976), "Some Implications of the Growth of the Mineral Sector", The Australian Journal of Agricultural Economics, 20: 71-91.

Gregory, R. G.(2011), ‘Then and now: Reflections on two Australian mining booms’, Centre for Strategic Economic Studies Working Paper no. 50, Victoria University.

(2012), "Living standards, terms of trade and foreign ownership: reflections on the Australian mining boom", The Australian Journal of Agricultural and Resource Economics, 56, 171-200.

Gunasekera, H.D.B. and R. Tyers (1990), "Imperfect Competition and Returns to Scale in a Newly Industrialising Economy: A General Equilibrium Analysis of Korean Trade Policy", Journal of Development Economics, 34: 223-247.

Harris, R.G. (1984), “Applied general equilibrium analysis of small open economies with scale economies and imperfect competition”, American Economic Review 74: 1016-1032.

Harris, R.G. and D. Cox (1983), Trade, Industrial Policy and Canadian Manufacturing, Toronto: Ontario Economic Council.

Harrison, J., J.M. Horridge, M. Jerie and K.R. Pearson (2013), GEMPACK Manual, Centre for Policy Studies, Melbourne, www.monash.edu.au/policy/gpmanual.htm.

Hertel, T.W., (1994), “The 'pro-competitive effects' of trade policy reform in a small, open economy”, Journal of International Economics, 36: 391-411.

Horridge, M. (1987), “The long term costs of protection: experimental analysis with different closures of and Australian computable general equilibrium model”, PhD dissertation, University of Melbourne.

Ianchovichina, E., J. Binkley and T.W. Hertel (2000), "Procompetitive effects of foreign competition on domestic markups", Review of International Economics, 8(1): 134-148.

Johansen, Leif (1960). A Multi-Sectoral Study of Economic Growth, North-Holland (2nd enlarged edition 1974).

Jones, R.W. (1971), “The three-factor model in theory, trade and history”, in J. Bhagwati et al. (eds), Trade, Balance of Payments and Growth, Amsterdam: North Holland.

Krueger, A.O. (1977), Growth, Distortions and Patterns of Trade Among Many Countries, Princeton N.J., International Finance Series. 
Lim, G.C., V.H. Nguyen and C.L. Chua (2014), "Review of the Australian Economy 2013-14: the age of austerity?” Australian Economic Review, 47(1): 1-12.

Melitz, Marc J. (2003), "The Impact of Trade on Intra-Industry Reallocations and Aggregate Industry Productivity," Econometrica, 71(6), 1695-1725.

Menezes, F.M. (2009), "Consistent regulation of infrastructure businesses: some economic issues," Economic Papers, 28(1): 2-10, March.

Mundell, R.A., 1963. "Capital mobility and stabilisation policy under fixed and flexible exchange rates”, Canadian Journal of Economics and Political Science, 29: 475-485.

Nepal, R., F.M. Menezes and T. Jamasb (2014), "Network regulation and regulatory institutional reform: revisiting the case of Australia", School of Economics Discussion Paper 510, University of Queensland, March.

Parham, D. (2013), “Australia’s productivity: past, present and future”, Australian Economic Review, 46(4): 462-472.

Quiggin, J. (2001), “The Australian productivity miracle: a sceptical view”, Agenda, 8(4): 333-348. (2006), “Stories about productivity”, Australian Bulletin of Labour, 32(1): 1826.

Reserve Bank of Australia (2012), 'Statistical Tables: Prices and Inflation’, Table G4, Reserve Bank of Australia. Available from: <http://www.rba.gov.au/statistics/tables/index.html\#exchange_rates $>$ [24 May 2012].

Sheehan, P. and R.G. Gregory (2013), "The resources boom and economic policy in the long run”, Australian Economic Review 46(2): 121-139.

Sieper, E., (1982), Rationalising Rustic Regulation, Centre for Independent Studies, Sydney.

Tyers, R. (2005), “Trade reform and manufacturing pricing behaviour in four archetype Asia-Pacific Economies”, Asian Economic Journal 19(2): 181-203, 2005. (2014), "Service oligopolies and Australia’s economy-wide performance”, Discussion Papers in Economics 14-18, UWA Business School, Perth, April

Tyers, R. and A. Walker (2013), “Quantifying Australia’s ‘three-speed’ boom”, CAMA Working Paper No.10/2013, ANU and UWA Business School Economics Discussion Paper 13.06, February.

Venables, A.J. (2010), "Resource rents: when to spend and how to save”, International Tax and Public Finance, 17, 340-356. 
Figure 1: Terms of Trade Shocks from Autarky in the Neoclassical Model
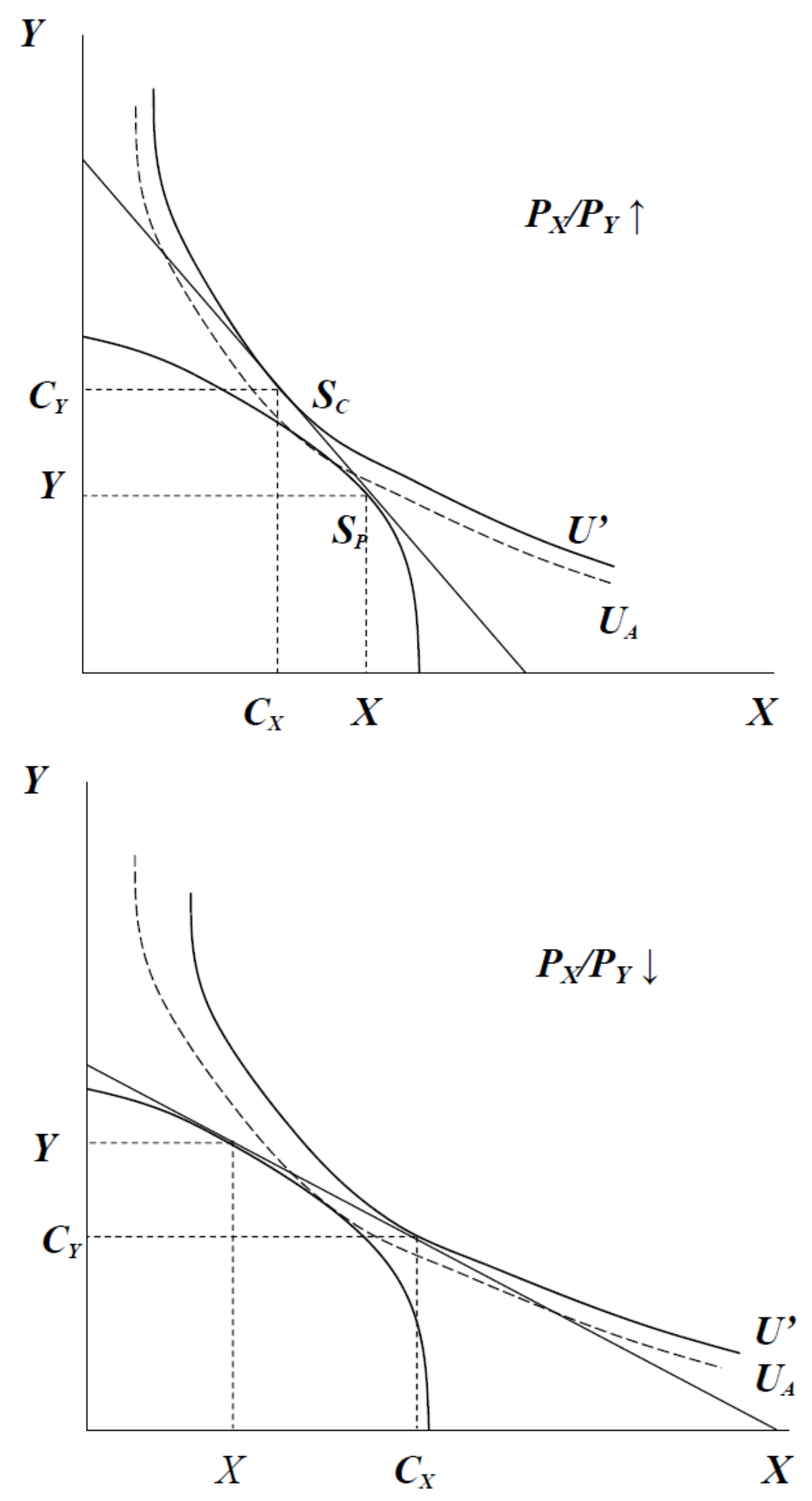
Figure 2: Welfare Effects of Terms of Trade Changes in the Neoclassical Model
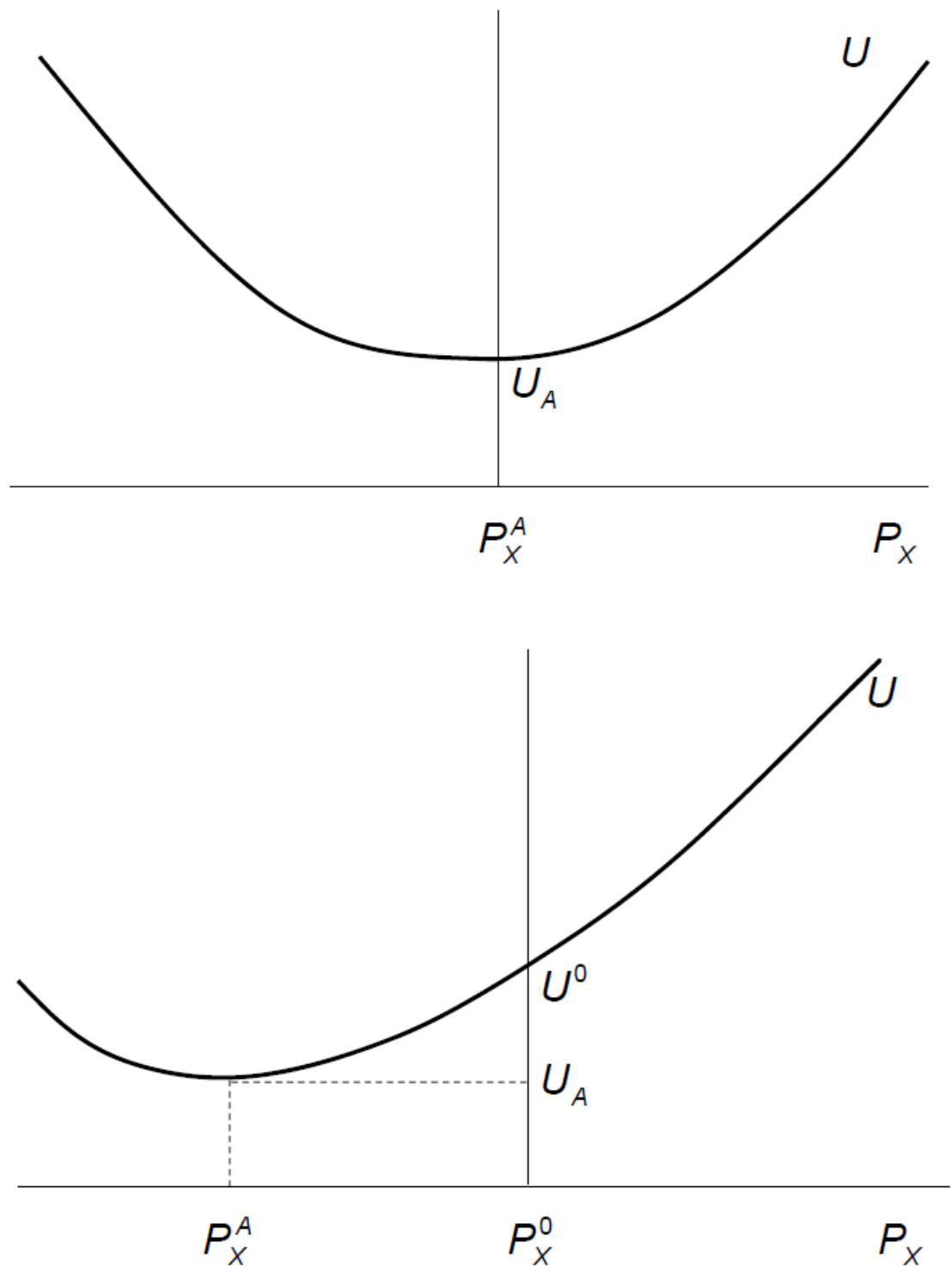
Figure 3: Cumulative Industry Shares of Firm Capital ${ }^{\mathrm{a}}$

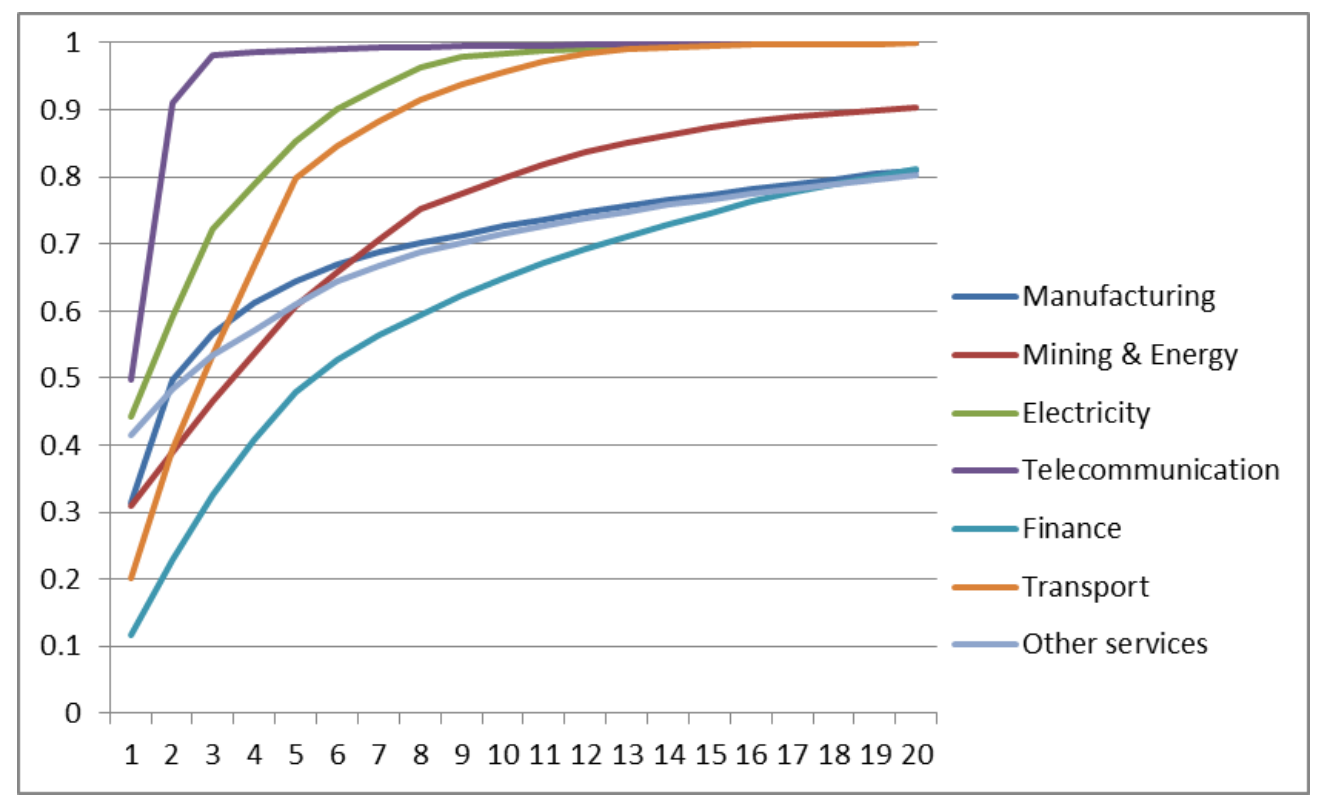

a Firm capital is market capitalisation plus net debt. Firms are ranked by size and shares of industry totals accumulated.

Source: Calculations based on Morningstar data for 2006. 
Figure 4: Long Run Effects of Terms of Trade Shocks
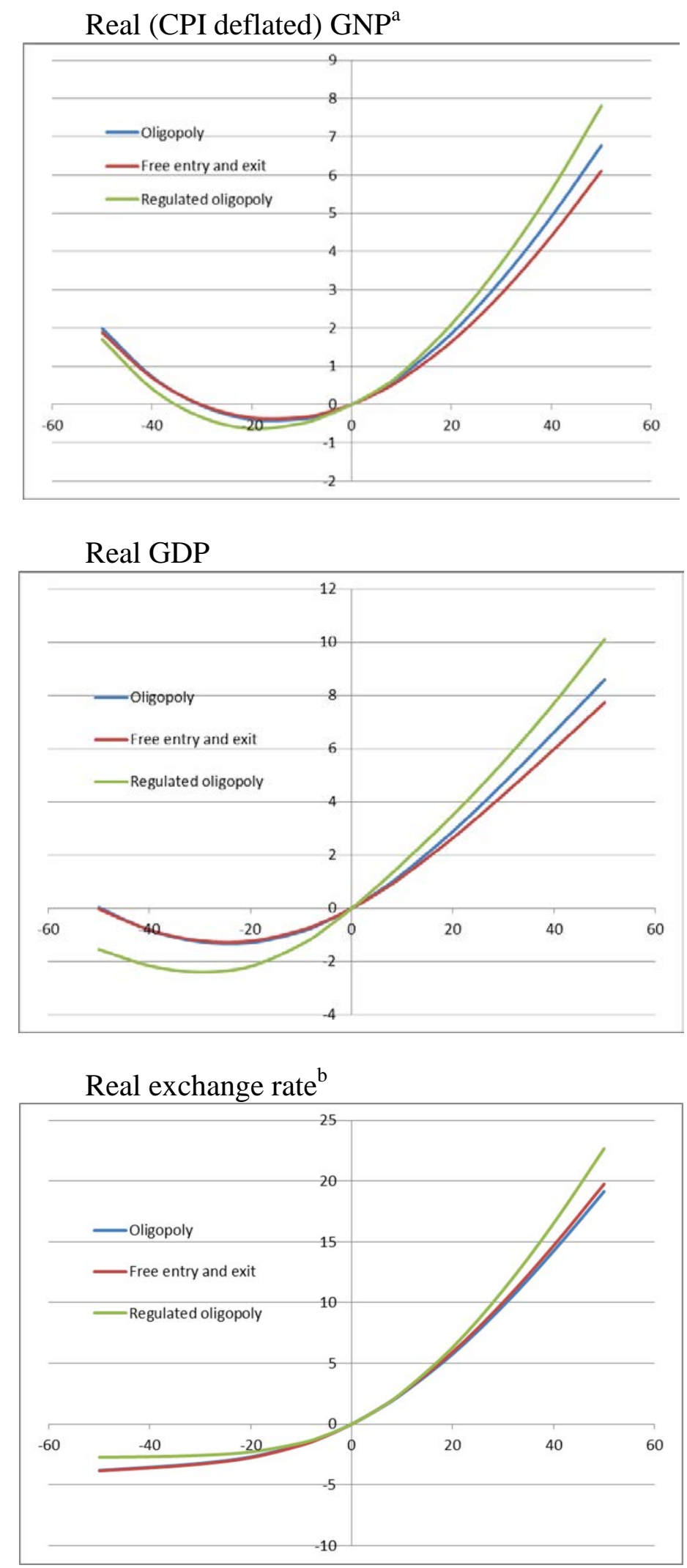

a The CPI used to deflate GNP is a perfect index based on the expenditure function and so the quotient is an aggregate welfare measure.

b The real exchange rate is the ratio of the home GDP price to the foreign one.

Sources: Model simulations described in the text. 
Figure 5: Short Run Effects of Terms of Trade Shocks
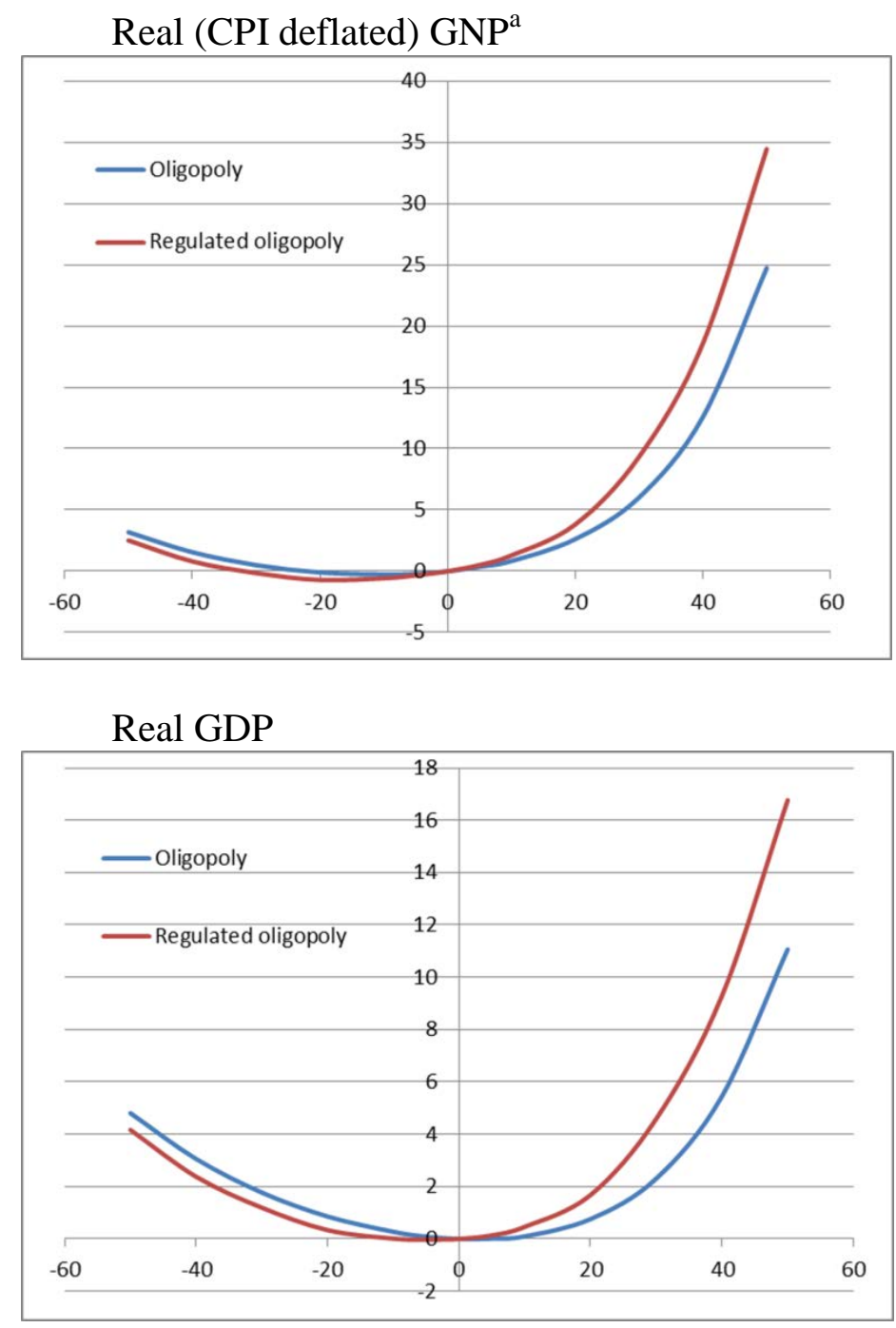

Real exchange rate ${ }^{\mathrm{b}}$

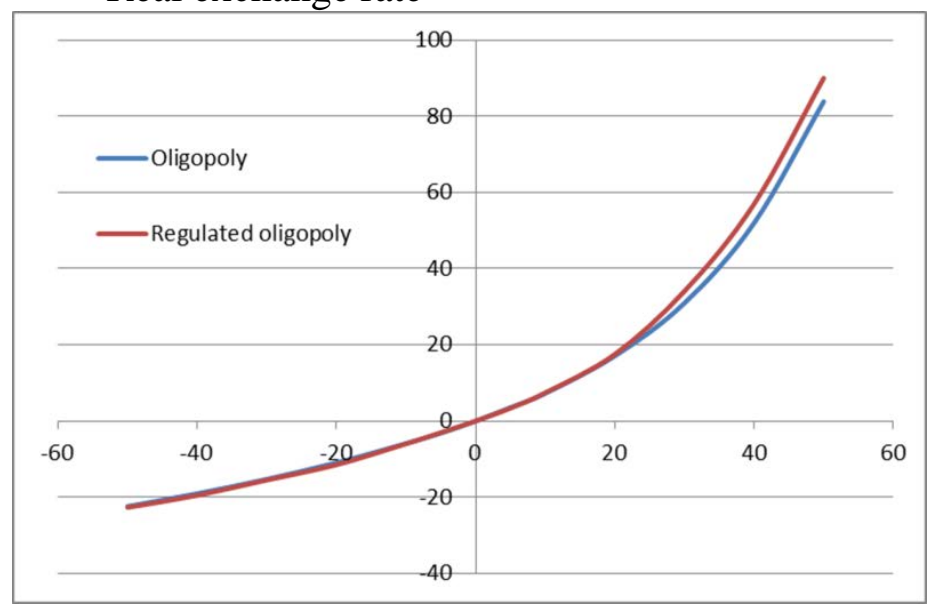

a The CPI used to deflate GNP is a perfect index based on the expenditure function and so the quotient is an aggregate welfare measure.

b The real exchange rate is the ratio of the home GDP price to the foreign one.

Sources: Model simulations described in the text. 
Table 1: Model structure

\begin{tabular}{|c|c|}
\hline Regions & $\begin{array}{l}\text { Australia } \\
\text { Rest of world }\end{array}$ \\
\hline Primary factors & $\begin{array}{l}\text { Natural resources (mineral, energy deposits) } \\
\text { Arable land } \\
\text { Skilled (professional) labour } \\
\text { Unskilled (production) labour } \\
\text { Physical capital }\end{array}$ \\
\hline Sectors & $\begin{array}{l}\text { Agriculture } \\
\text { Manufacturing } \\
\text { Mining, petroleum and minerals } \\
\text { Electricity } \\
\text { Water } \\
\text { Gas manufacture and distribution } \\
\text { Telecommunications } \\
\text { Finance and insurance } \\
\text { Transport } \\
\text { Other services }\end{array}$ \\
\hline
\end{tabular}

Source: Aggregates from the GTAP VII database.

\section{Table 2: Economic Structure}

\begin{tabular}{lcccc}
\hline & $\begin{array}{c}\text { Value added } \\
\text { share of GDP }\end{array}$ & $\begin{array}{c}\text { Share of } \\
\text { total exports }\end{array}$ & $\begin{array}{c}\text { Export share } \\
\text { of output }\end{array}$ & $\begin{array}{c}\text { Net exports } \\
\text { over output }\end{array}$ \\
\hline Agriculture & 3.0 & 7.0 & 23.9 & 21.5 \\
Manufacturing & 11.9 & 41.4 & 24.1 & -16.5 \\
Mining & 8.7 & 31.5 & 38.8 & 25.9 \\
Electricity & 1.3 & 0.0 & 0.0 & 0.0 \\
Water & 0.7 & 0.1 & 1.6 & 1.0 \\
Gas Distribution & 0.1 & 0.1 & 7.7 & -13.1 \\
Telecommunications & 2.4 & 0.7 & 2.7 & -0.1 \\
Finance & 7.2 & 1.7 & 3.0 & 0.6 \\
Transport & 15.7 & 9.0 & 5.2 & 0.7 \\
Other Services & 49.0 & 8.6 & 1.9 & 0.1 \\
\hline
\end{tabular}

Source: Model database (social accounting matrix), derived from the GTAP global database for 2007.

Table 3: Factor Intensities by Industry ${ }^{a}$

\begin{tabular}{lccccc}
\hline & $\begin{array}{c}\text { Physical } \\
\text { capital }\end{array}$ & $\begin{array}{c}\text { Production } \\
\text { labour }\end{array}$ & $\begin{array}{c}\text { Skilled } \\
\text { labour }\end{array}$ & $\begin{array}{c}\text { Arable } \\
\text { land }\end{array}$ & $\begin{array}{c}\text { Natural } \\
\text { resources }\end{array}$ \\
\hline Agriculture & 26.8 & 48.5 & 4.4 & 17.7 & 2.6 \\
Manufacturing & 24.1 & 54.5 & 21.1 & 0.3 & 0.0 \\
Mining \& energy & 60.4 & 16.4 & 5.5 & 0.0 & 17.7 \\
Electricity & 59.3 & 24.8 & 15.9 & 0.0 & 0.0 \\
Water & 55.7 & 22.6 & 12.5 & 9.3 & 0.0 \\
Gas Distribution & 67.2 & 17.8 & 15.0 & 0.0 & 0.0 \\
Telecommunications & 57.1 & 19.4 & 23.4 & 0.0 & 0.0 \\
Finance & 42.0 & 20.7 & 37.3 & 0.0 & 0.0 \\
Transport & 22.9 & 54.5 & 22.6 & 0.0 & 0.0 \\
Other Services & 33.5 & 30.9 & 35.6 & 0.0 & 0.0 \\
\hline
\end{tabular}

a These are factor shares of total value added in each industry, calculated from the database. Shares sum to 100 per cent horizontally.

Source: Model database (social accounting matrix), derived from the GTAP Database 2007. 
Table 4: Initial Demand Elasticities and Mark-ups ${ }^{\mathrm{a}}$

\begin{tabular}{lccccccc}
\hline & Final & Government & Investment & Intermediate & Export & $\begin{array}{c}\text { Average } \\
\text { demand } \\
\text { elasticity }\end{array}$ & $\begin{array}{c}\text { Industry } \\
\text { mark- } \\
\text { ups, } \%^{\mathrm{b}}\end{array}$ \\
\hline Agriculture & -14.0 & -14.0 & -7.0 & -7.0 & -14.3 & -9.8 & 11.3 \\
Manufacturing & -12.7 & -12.8 & -6.4 & -5.7 & -13.6 & -9.1 & 12.4 \\
Mining \& energy & -10.5 & -10.4 & -5.2 & -6.4 & -12.2 & -8.9 & 12.6 \\
Electricity & -7.2 & -7.2 & -3.8 & -4.0 & -9.0 & -4.8 & 26.6 \\
Water & -9.9 & -9.9 & -5.1 & -4.3 & -11.2 & -7.0 & 16.6 \\
Gas Distribution & -6.3 & -6.5 & -3.0 & -3.1 & -8.2 & -3.7 & 37.0 \\
Telecommunications & -6.6 & -6.6 & -3.4 & -2.7 & -8.7 & -4.0 & 33.2 \\
Finance & -8.7 & -8.7 & -4.4 & -4.7 & -10.0 & -6.2 & 19.3 \\
Transport & -8.7 & -8.7 & -4.4 & -3.4 & -10.0 & -6.2 & 19.3 \\
Other Services & -12.7 & -12.7 & -6.3 & -4.2 & -13.1 & -8.0 & 14.3 \\
\hline
\end{tabular}

a Elasticities are calculated via the equations in the appendices, where elasticities of substitution are sourced from surveys cited by Harris and Cox (1984) and Dimaranan and McDougall (2002).

All these variables are endogenous in the model. Initial (base) values are provided here.

b Industry mark-ups are of producer prices over average variable costs.

\section{Table 5: Calibrated Pure Profit, Cost Shares and Industry Scale}

\begin{tabular}{lcccc}
\hline Per cent of industry turnover & Pure profit $^{\mathrm{a}}$ & Fixed cost $^{\mathrm{a}}$ & Variable cost $^{\mathrm{a}}$ & Scale $^{\mathrm{b}}$ \\
\hline Agriculture & 1.0 & 8.9 & 90.1 & 50.7 \\
Manufacturing & 0.7 & 10.1 & 89.2 & 44.1 \\
Mining & 2.3 & 8.1 & 89.6 & 54.8 \\
Electricity & 6.1 & 14.1 & 79.8 & 28.1 \\
Water & -7.0 & 21.4 & 85.7 & 20.1 \\
Gas distribution & 2.5 & 24.1 & 73.5 & 15.2 \\
Telecommunications & 4.2 & 19.6 & 76.1 & 19.1 \\
Finance & 10.6 & 2.6 & 86.8 & 91.2 \\
Transport & -1.5 & 17.9 & 83.6 & 23.4 \\
Other Services & 0.2 & 12.3 & 87.5 & 35.7 \\
\hline
\end{tabular}

a The final three columns of the table are calibrated. First, elasticities are estimated, from which markup ratios are calculated. The pure profit shares of total revenue are then used to deduce the fixed cost residual.

b Scale is defined as the ratio (in \%) of the gross quantity produced and minimum efficient scale, which in turn, is the level of output where unit fixed cost is $5 \%$ of unit variable cost.

Source: Pure profit proportions are from the Morningstar Financial Analysis Database of listed Australian firms. 


\section{Table 6: Closures Used}

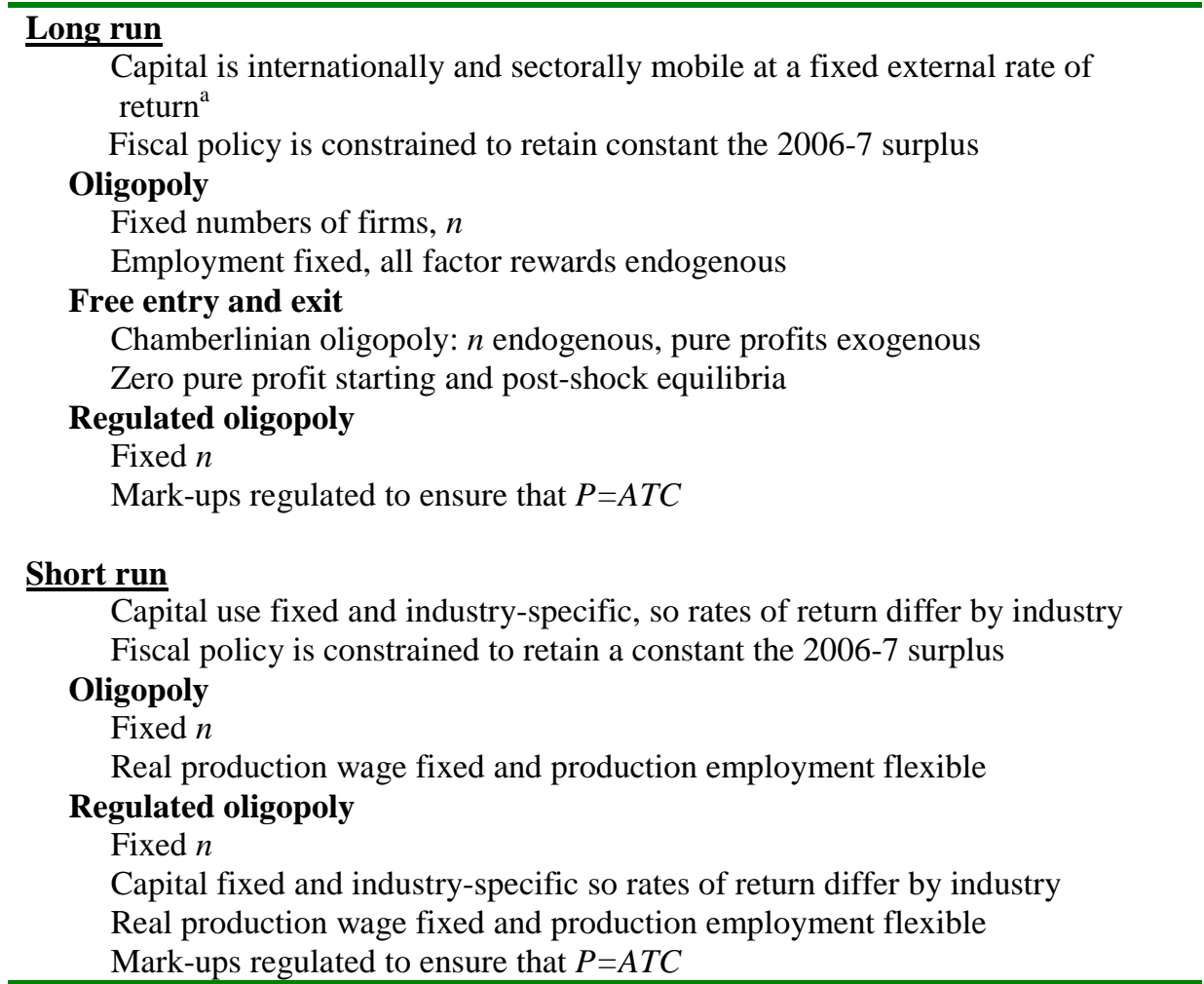

a The stock of home-owned capital is fixed so that long run changes in capital stocks change the proportion of foreign owned capital and hence the financial outflow associated with profit repatriation. 
Table 7: Aggregate Effects of Terms of Trade Shocks ${ }^{\text {a }}$

\begin{tabular}{|c|c|c|c|c|c|c|}
\hline \multirow[b]{2}{*}{ Per cent change } & \multicolumn{2}{|c|}{ Oligopoly } & \multicolumn{2}{|c|}{ Free entry/exit } & \multicolumn{2}{|c|}{ Regulated oligopoly } \\
\hline & $+30 \%$ & $-30 \%$ & $+30 \%$ & $-30 \%$ & $+30 \%$ & $-30 \%$ \\
\hline \multicolumn{7}{|l|}{ Long run } \\
\hline Real GNP & 3.3 & 0.0 & 2.9 & 0.0 & 3.7 & -0.3 \\
\hline Real GDP & 4.7 & -1.3 & 4.3 & -1.2 & 5.5 & -2.3 \\
\hline Real exchange rate & 9.7 & -3.2 & 10.0 & -3.3 & 11.0 & -2.6 \\
\hline Gross rate of return $^{\mathrm{d}}$ & 1.5 & -0.1 & 0.0 & 0.0 & 0.0 & 0.0 \\
\hline Capital stock & 11.9 & -6.2 & 12.6 & -6.4 & 15.6 & -8.1 \\
\hline Investment/GDP & 2.1 & -0.6 & 2.1 & -0.6 & 2.4 & -0.4 \\
\hline Foreign Inv/GDP & -0.6 & 0.3 & -0.4 & 0.3 & -0.6 & 0.6 \\
\hline Govt exp/GDP & 5.3 & -1.8 & 5.3 & -1.8 & 6.4 & -2.0 \\
\hline Current Acc /GDP & 0.7 & -0.3 & 0.5 & -0.3 & 0.8 & -0.6 \\
\hline \multicolumn{7}{|l|}{ Short run ${ }^{\mathrm{b}}$} \\
\hline Real GNP ${ }^{\mathrm{c}}$ & 5.8 & 0.5 & & & 7.8 & 0.2 \\
\hline Real GDP & 2.2 & 1.8 & & & 3.7 & 1.5 \\
\hline Real exchange rate & 30.3 & -15.2 & & & 30.7 & -15.2 \\
\hline Gross rate of return $^{\mathrm{d}}$ & 8.7 & -3.1 & & & 8.3 & -3.2 \\
\hline Capital stock & 0.0 & 0.0 & & & 0.0 & 0.0 \\
\hline Investment/GDP & 26.0 & -9.2 & & & 29.2 & -9.6 \\
\hline Foreign Inv/GDP & 21.1 & -7.7 & & & 23.8 & -8.0 \\
\hline Govt exp/GDP & 11.4 & -4.8 & & & 12.9 & -5.0 \\
\hline Current Acc /GDP & -19.7 & 6.5 & & & -22.4 & 6.9 \\
\hline
\end{tabular}

a The shocks here are to first raise the international prices of agricultural products, mining and energy products by $30 \%$ and, second, to lower them by the same margin. "Oligopoly" refers to fixed numbers of firms with unfettered oligopoly pricing. "Free entry/exit" allows firm numbers to adjust to ensure there are no pure (economic) profits. "Regulated oligopoly" maintains fixed firm numbers but requires them to price so as just to cover the entirety of their average costs.

b The long run allows free international mobility of capital at an external market rate of return along with full real wage adjustment to clear labour markets. The short run fixes the capital stock in each industry and the real wage of production workers.

c Real GNP is deflated by the consumer price index.

d This is the rate of return on all physical capital, including pure profits.

Source: Simulations of the model described in the text. 
Table 8: Key Sectoral Long Run Effects of Terms of Trade Shocks ${ }^{\text {a }}$

\begin{tabular}{|c|c|c|c|c|c|c|}
\hline \multirow[b]{2}{*}{ Per cent change } & \multicolumn{2}{|c|}{ Oligopoly } & \multicolumn{2}{|c|}{ Free entry/exit $^{\mathrm{b}}$} & \multicolumn{2}{|c|}{ Regulated oligopoly } \\
\hline & $+30 \%$ & $-30 \%$ & $+30 \%$ & $-30 \%$ & $+30 \%$ & $-30 \%$ \\
\hline \multicolumn{7}{|l|}{ Mark-up ratios } \\
\hline Agriculture & -1.3 & 1.9 & -1.3 & 2.0 & -3.9 & 3.9 \\
\hline Manufacturing & 1.4 & -0.6 & 1.5 & -0.6 & 6.9 & -1.9 \\
\hline Mining \& energy & -1.3 & 3.3 & -1.4 & 3.6 & -3.7 & 9.3 \\
\hline Transport & 0.4 & -0.2 & 0.4 & -0.2 & 1.0 & -0.5 \\
\hline Other services & -0.2 & 0.1 & -0.2 & 0.1 & -0.6 & 0.2 \\
\hline Weighted average & 0.1 & 0.2 & 0.1 & 0.2 & 0.7 & 0.5 \\
\hline \multicolumn{7}{|l|}{ Pure profits/GDP } \\
\hline Agriculture & 0.3 & -0.1 & 0 & 0 & 0 & 0 \\
\hline Manufacturing & -0.7 & 0.4 & 0 & 0 & 0 & 0 \\
\hline Mining \& energy & 1.2 & -0.6 & 0 & 0 & 0 & 0 \\
\hline Transport & -0.1 & 0.1 & 0 & 0 & 0 & 0 \\
\hline Other services & 1.1 & -0.2 & 0 & 0 & 0 & 0 \\
\hline Total & 0.3 & -0.1 & 0 & 0 & 0 & 0 \\
\hline \multicolumn{7}{|l|}{ Scale ${ }^{c}$} \\
\hline Agriculture & 52.5 & -26.2 & 7.2 & -11.6 & 63.2 & -27.0 \\
\hline Manufacturing & -28.0 & 20.2 & -13.2 & 7.6 & -42.0 & 24.7 \\
\hline Mining \& energy & 66.5 & -41.9 & 4.8 & -15.5 & 81.3 & -50.4 \\
\hline Transport & -5.1 & 3.9 & -3.9 & 2.5 & -6.7 & 4.1 \\
\hline Other services & 3.2 & -0.9 & 1.4 & -0.4 & 4.3 & -1.5 \\
\hline Average & 2.5 & -0.3 & -1.9 & 0.4 & 2.6 & -1.1 \\
\hline \multicolumn{7}{|l|}{ Entries/Initial firms } \\
\hline Agriculture & 0 & 0 & 17.4 & -7.0 & 0 & 0 \\
\hline Manufacturing & 0 & 0 & -1.4 & 1.0 & 0 & 0 \\
\hline Mining \& energy & 0 & 0 & 3.0 & -1.6 & 0 & 0 \\
\hline Transport & 0 & 0 & -0.1 & 0.1 & 0 & 0 \\
\hline Other services & 0 & 0 & 0.6 & -0.2 & 0 & 0 \\
\hline Total & 0 & 0 & 19.6 & -7.7 & 0 & 0 \\
\hline \multicolumn{7}{|l|}{ Fixed cost/GDP } \\
\hline Agriculture & 0.0 & 0.0 & 0.3 & -0.1 & 0.0 & 0.0 \\
\hline Manufacturing & 0.3 & -0.1 & -0.4 & 0.3 & 0.3 & -0.1 \\
\hline Mining \& energy & 0.1 & 0.0 & 1.2 & -0.6 & 0.1 & 0.0 \\
\hline Transport & 0.5 & -0.1 & 0.4 & 0.0 & 0.6 & -0.1 \\
\hline Other services & 0.9 & -0.2 & 1.1 & -0.3 & 1.0 & -0.2 \\
\hline Total & 2.0 & -0.5 & 2.9 & -0.8 & 2.2 & -0.5 \\
\hline \multicolumn{7}{|l|}{ Gross output } \\
\hline Agriculture & 52.5 & -26.2 & 51.5 & -26.2 & 63.2 & -27.0 \\
\hline Manufacturing & -28.0 & 20.2 & -28.9 & 20.7 & -42.0 & 24.7 \\
\hline Mining \& energy & 66.5 & -41.9 & 66.2 & -42.3 & 81.3 & -50.4 \\
\hline Electricity & -2.2 & 4.1 & -2.5 & 4.1 & -2.3 & 1.9 \\
\hline Water & -0.2 & 1.8 & -0.3 & 1.8 & 1.1 & 0.9 \\
\hline Gas & -4.4 & 5.7 & -4.1 & 5.3 & -1.9 & 0.0 \\
\hline Telecoms & -2.3 & 2.0 & -2.7 & 2.2 & -3.8 & 2.3 \\
\hline Finance & -1.2 & 0.4 & -1.7 & 0.5 & -2.6 & 0.5 \\
\hline Transport & -5.1 & 3.9 & -5.5 & 4.1 & -6.7 & 4.1 \\
\hline Other services & 3.2 & -0.9 & 2.9 & -0.9 & 4.3 & -1.5 \\
\hline \multicolumn{7}{|l|}{$(X-M) / G D P$} \\
\hline Agriculture & 2.7 & -1.6 & 2.7 & -1.6 & 3.3 & -1.6 \\
\hline Manufacturing & -8.6 & 5.2 & -8.6 & 5.2 & -11.6 & 6.1 \\
\hline Mining \& energy & 9.4 & -7.0 & 9.3 & -7.0 & 12.7 & -8.6 \\
\hline
\end{tabular}

a The shocks here are to first raise the international prices of agricultural products, mining and energy products by $30 \%$ and, second, to lower them by the same margin. "Oligopoly” refers to fixed numbers of firms with unfettered oligopoly pricing. "Free entry/exit" allows firm numbers to adjust to ensure there are no pure (economic) profits. "Regulated oligopoly" maintains fixed firm numbers but requires them to price so as just to cover the entirety of their average costs. The long run allows free international mobility of capital at an external market rate of return along with full real wage adjustment to clear labour markets. b The "free entry and exit" simulation begins from a zero pure profit development of the initial equilibrium, generated by a long run simulation in which entry and exit are free and pure profits are shocked down to zero.

b Scale is defined as the ratio (in \%) of the gross quantity produced and minimum efficient scale, which in turn, is the level of output where unit fixed cost is $5 \%$ of unit variable cost.

Source: Simulations of the model described in the text. 


\section{Appendices to:}

\section{Asymmetry in Boom-Bust Shocks: \\ Australian Performance with Oligopoly}

\section{A.1: The Model in Detail}

This appendix complements the presentation of the model offered in the main text and so the analytics offered there are not repeated. It emphasises the representation of demand and production technology in the model and it details the tax system that is built into it. Although the model simulates only the real economy, an exchange rate is defined in the equations as a solution device. In one available closure its value adjusts to satisfy a balance of payments condition, thereby bringing about changes in domestic relative to international prices. Most often, however, an alternative closure is adopted in which the balance of payments condition is eliminated from the model and the artificial exchange rate fixed, so that all the adjustments to shocks are made by the home prices relative to those of imported products, which constitute the numeraire. The balance of payments condition is still met because it is implied by the household's and the government's budget constraints.

\section{Mark-ups:}

Oligopolistic firms operate in differentiated product markets and so each chooses its price, and hence mark-up, to take advantage of its monopoly over the supply of its own product variety. Thus, within each industry, each firm faces an elasticity of demand that depends on the number of other firms and the degree of pricing collusion between firms. Symmetry within each sector implies a common optimal unregulated mark-up for each firm, as in equation (8) of the main text.

\section{Demand elasticities}

These depend on the structure of the model, to be detailed below. They are essential to the capture of oligopoly behaviour since they determine the size of mark-up ratios, via equations (8) through (10) in the main text. For final demand the elasticity expression is:

(A1.1) $\varepsilon_{i}^{F}=-\eta_{i}^{F}+\frac{1}{n_{i}}\left\{\left(\sigma_{i}^{F}-1\right) \delta_{i}^{F}\left(\frac{\hat{P}_{i H}}{\hat{P}_{i}^{F}}\right)^{\left(1-\sigma_{i}^{F}\right)}+\left(\eta_{i}^{F}-\sigma_{i}^{F}\right)\left(1+\left(n_{i}-1\right) \mu_{i}\right)\right\}$,

where $\eta_{i}^{F}$ is the elasticity of substitution of final demand across home varieties in sector $i, \delta_{i}^{F}$ is the home share in final demand for product $i, \sigma_{i}^{F}$ is the elasticity of substitution of final demand for good $i$ between domestic and foreign countries, $n_{i}$ is the number of domestic firms in industry $i, \hat{P}_{i H}$ is the CES composite price of all home varieties of product $i$, and $\hat{P}_{i}^{F}$ is the CES composite of home and foreign final product 
prices in the domestic market, weighted by domestic consumption shares. Equation (A1.1) is derived in A.2, below.

The behaviour of government consumption and the expenditure of the capital goods sector on home and foreign products are similar, except that the government pays no import duties or consumption tax and the capital goods sector pays no import duties. Their composite prices are therefore formulated differently. Their structure is nonetheless the same:

(A1.2) $\varepsilon_{i}^{G}=-\eta_{i}^{G}+\frac{1}{n_{i}}\left\{\left(\sigma_{i}^{G}-1\right) \delta_{i}^{G}\left(\frac{\hat{P}_{i H}}{\hat{P}_{i}^{G}}\right)^{\left(1-\sigma_{i}^{G}\right)}+\left(\eta_{i}^{G}-\sigma_{i}^{G}\right)\left(1+\left(n_{i}-1\right) \mu_{i}\right)\right\}$,

(A1.3) $\varepsilon_{i}^{V}=-\eta_{i}^{V}+\frac{1}{n_{i}}\left\{\left(\sigma_{i}^{V}-1\right) \delta_{i}^{V}\left(\frac{\widehat{P}_{i H}}{\hat{P}_{i}^{V}}\right)^{\left(1-\sigma_{i}^{V}\right)}+\left(\eta_{i}^{V}-\sigma_{i}^{V}\right)\left(1+\left(n_{i}-1\right) \mu_{i}\right)\right\}$.

For the intermediate demand elasticity a similar expression is obtained:

(A1.4) $\varepsilon_{i}^{I}=\sum_{j=1}^{N} s_{i j}{ }^{I}\left[-\eta_{i}^{I}+\frac{1}{n_{i}}\left(\gamma_{i j}+\sigma_{i}^{I}-1\right) \phi_{i j}\left(\frac{\hat{P}_{i H}}{\hat{P}_{i}^{I}}\right)^{1-\sigma_{i}^{I}}+\left(\eta_{i}^{I}-\sigma_{i}^{I}\right)\left(1+\left(n_{i}-1\right) \mu_{i}\right)\right]$,

where $s_{i j}{ }^{I}$ is the share of industry $j$ in the total intermediate demand for input $i$ and $\hat{P}_{i}^{I}$ is the CES composite of home and foreign intermediate product prices in the domestic market, weighted by domestic intermediate consumption shares.

For exports it is assumed that home firms face such competition in foreign markets that non-collusive pricing behaviour is necessitated. The foreign demand elasticity takes the same form as (A1.1), except that the foreign conjectural variation parameter, $\mu_{i}^{X}$, is zero:

$$
\begin{aligned}
& \varepsilon_{i}^{X}=-\eta_{i}^{X}+\frac{1}{n_{i}}\left\{\left(\sigma_{i}^{X}-1\right) \theta_{i}\left(\frac{\hat{P}_{i}^{e}}{\hat{P}_{i}^{X}}\right)^{\left(1-\sigma_{i}^{X}\right)}+\left(\eta_{i}^{X}-\sigma_{i}^{X}\right)\left(1+\left(n_{i}-1\right) \mu_{i}^{X}\right)\right\} \\
& =-\eta_{i}^{X}+\frac{1}{n_{i}}\left\{\left(\sigma_{i}^{X}-1\right) \theta_{i}\left(\frac{\hat{P}_{i}^{e}}{\hat{P}_{i}^{X}}\right)^{\left(1-\sigma_{i}^{X}\right)}+\left(\eta_{i}^{X}-\sigma_{i}^{X}\right)\right\},
\end{aligned}
$$

where $\hat{P}_{i}^{e}$ is the CES composite foreign currency price of all exported varieties of product $I$ and $\hat{P}_{i}^{X}$ is the CES composite of exported and competing foreign final product prices in the foreign market, weighted by foreign consumption shares. Foreigners differentiate home exports from corresponding foreign products with elasticity of substitution $\sigma_{i}^{X}$ and home varieties from one another with elasticity of substitution $\eta_{i}^{X}$.

\section{Domestic prices of imported goods:}

These are:

(A1.6) $p_{i}^{*}=\frac{p_{i}^{w}\left(1+\tau_{i}^{M}\right)\left(1+\tau_{i}^{C}\right)}{e}$ 
where $p_{i}^{w}$ is the exogenous foreign currency price of goods produced in the rest of the world, $\tau_{i}^{M}$ is the ad valorem tariff rate and $\tau_{i}^{C}$ is the consumption tax rate on final demand for the products of industry $i$.

\section{Domestic prices of home products:}

As in equation (8) of the main text, these are marked up over average variable cost. To obtain average variable cost, note that production is Cobb-Douglas in variable factors and inputs, with output elasticities $\alpha_{i}$ for capital, $\beta_{k i}$ for factors $\mathrm{k}$ and $\gamma_{j i}$ for inputs $j$ and that the subaggregation of imported and domestic inputs is CES. Unit variable costs are therefore calculated as:

$$
\text { (A1.7) } v_{i}=b_{i} r^{\alpha_{i}} \prod_{k=1}^{K} w_{k}^{\beta_{k i}} \prod_{j=1}^{N}\left[\hat{P}_{j i}^{I}\right]^{\gamma_{j i}} \quad \forall i
$$

where the scale coefficient $b_{i}$ is calibrated from the SAM, as are all the exponents in the equation, and $\hat{P}_{j i}{ }^{I}$ is a CES composite of home and imported input prices weighted by the domestic and imported shares specific to consuming industry $i$ :

(A1.8) $\hat{P}_{j i}^{I}=\left[\phi_{j i}\left(p_{j}\right)^{\left(1-\sigma_{j}^{I}\right)}+\left(1-\phi_{j i}\right)\left(p_{j}^{*}\right)^{\left(1-\sigma_{j}^{I}\right)}\right]^{\frac{1}{1-\sigma_{j}^{I}}}$

where $\phi_{j i}$ is the domestic share of inputs from industry $j$ in use by industry $i$. Then, domestic producer prices are simply higher by the mark-up, $m_{i}: p_{i}=m_{i} v_{i}, \quad \forall i$.

\section{Unit factor and input demands:}

A full set of inter-industry flows is characterised in the model. The volumes of each intermediate demand are derived by solving the firm's cost minimisation problem with Cobb-Douglas production in variable factors and inputs. It is assumed that firms have no monopsony power in either factor or input markets. Therefore, the unit factor demands for capital and other factors are:

$$
\text { (A1.9) } u_{i}^{K}=\frac{\alpha_{i} v_{i}}{r} \quad \forall i, \quad \text { and } \quad u_{k i}^{L}=\frac{\beta_{k i} v_{i}}{w_{k}} \quad \forall k, i
$$

where $k$ denotes non-capital factors which are natural resources and skilled and unskilled labour.

The corresponding unit input demands are Leontief input-output coefficients, except that their values depend on product and input prices. For home-produced and imported inputs from industry $i$ used in the product of industry $j$, respectively they are:

$$
A_{i j}=\gamma_{i j} \frac{\phi_{i j} v_{j}}{\hat{P}_{i j}^{I}}\left(\frac{p_{i}}{\hat{P}_{i j}^{I}}\right)^{-\sigma_{i}^{I}}, \quad A_{i j}^{*}=\gamma_{i j} \frac{\left(1-\phi_{i j}\right) v_{j}}{\hat{P}_{i j}^{I}}\left(\frac{p_{i}^{*}}{\hat{P}_{i j}^{I}}\right)^{-\sigma_{i}^{I}} \quad \forall i, j .
$$




\section{Prices of home product exports in foreign markets:}

These are in foreign currency so they depend on the home producer price, the exchange rate, the export subsidy rate $s_{i}^{X}$ and the foreign import tariff rate, $\tau_{i}^{* M}$ :

$$
p_{i}^{e}=\frac{p_{i} e\left(1+\tau_{i}^{* M}\right)}{\left(1+s_{i}^{X}\right)} \quad \forall i
$$

\section{Export demand:}

Foreigners differentiate home exports from corresponding foreign products with elasticity of substitution $\sigma_{i}^{X}(>0)$ and home varieties from one another with elasticity of substitution $\eta_{i}^{X}$. This gives the following expression for foreign demand for variety $j$ of home product $i$ :

$$
X_{i j}=\frac{\theta_{i}}{n_{i}}\left(\frac{E_{i}}{\hat{P}_{i}^{X}}\right)\left(\frac{p_{i}^{e 0}}{\hat{P}_{i}^{X 0}}\right)^{\Delta \sigma_{i}^{X}}\left(\frac{p_{i}^{e}}{\hat{P}_{i}^{X}}\right)^{-\left(\sigma_{i}^{X}+\Delta \sigma_{i}^{X}\right)}\left(\frac{p_{i H j}}{\hat{P}_{i}^{e}}\right)^{-\eta_{i}^{X}},
$$

where $\theta_{i}$ is the calibrated reference share of the home export in total consumption, $E_{i}$ is a calibrated constant representing foreign expenditure on exports from industry $i$, and $\hat{P}_{i}^{X}$ is a CES composite of the home export price, $p_{i}^{e}$, and the foreign product price, $p_{i}^{w}$ , in the foreign market, weighted by foreign consumption shares. $\Delta \sigma_{i}^{X}$ is a shock that can be applied under short run conditions to reduce trade elasticities without affecting the database calibration. It requires the inclusion in the equation of the initial values for the home export price, $p_{i}^{e 0}$, and the composite price of products abroad, $\hat{P}_{i}^{X 0}$, so that the constant term is re-calibrated by the shock.

\section{Final demand:}

Home consumers differentiate home products from corresponding foreign products with elasticity of substitution $\sigma_{i}^{F}(>0)$ and home varieties from one another with elasticity of substitution $\eta_{i}^{F}$. They have Cobb-Douglas utility in broad product groups, with the result that expenditure shares are constant across these groups. Final demand for variety $j$ of home product group $i$ is therefore:

$$
D_{i H j}=\frac{\delta_{i}^{F} a_{i}^{F}}{n_{i}}\left(\frac{Y-T_{Y}}{\hat{P}_{i}^{F}}\right)\left(\frac{\hat{P}_{i H}}{\hat{P}_{i}^{F}}\right)^{-\sigma_{i}^{F}}\left(\frac{p_{i H j}}{\widehat{P}_{i H}}\right)^{-\eta_{i}^{F}} .
$$

where $a_{i}^{F}$ is the calibrated reference expenditure share of product group $i, \delta_{i}^{F}$ is the corresponding share of home goods in final demand for product $i, Y$ is GNP, $T_{Y}$ is total direct (income) tax, and the composite price is:

$$
\hat{P}_{i}^{F}=\left[\delta_{i}^{F}\left(p_{i H}\right)^{\left(1-\sigma_{i}^{F}\right)}+\left(1-\delta_{i}^{F}\right)\left(p_{i}^{*}\right)^{\left(1-\sigma_{i}^{F}\right)}\right]^{\frac{1}{1-\sigma_{i}^{F}}},
$$

where the home share is $\delta_{i}^{F}$. The expression for imports is correspondingly given by: 


$$
M_{i}^{F}=\left(1-\delta_{i}^{F}\right) a_{i}^{F}\left(\frac{Y-T_{Y}}{\hat{P}_{i}^{F}}\right)\left(\frac{p_{i}^{*}}{\hat{P}_{i}^{F}}\right)^{-\sigma_{i}^{F}}
$$

\section{Government demand:}

The formulation adopted is similar to that for final demand by households. Total government expenditure, $G$, is endogenous in the simulations presented in the main text, where it is assumed that the government maintains a fixed fiscal deficit. In other applications it is possible to allow for fiscal policy shocks with exogenous government spending and hence changes in government borrowing and capital account flows via equation (2) in the main text.

Tax revenue, and therefore the fiscal surplus or deficit, is endogenous, determined by the level of economic activity. Government expenditure is turned into demand for home produced products and imports, respectively, is given by:

$$
G_{i H j}=\frac{\delta_{i}^{G} a_{i}^{G}}{n_{i}}\left(\frac{G}{\hat{P}_{i}^{G}}\right)\left(\frac{\hat{P}_{i H}}{\hat{P}_{i}^{G}}\right)^{-\sigma_{i}^{G}}\left(\frac{p_{i H j}}{\hat{P}_{i H}}\right)^{-\eta_{i}^{G}},
$$

$G_{i}^{*}=\left(1-\delta_{i}^{G}\right) a_{i}^{G}\left(\frac{G}{\hat{P}_{i}^{G}}\right)\left(\frac{p_{i}^{*}}{\hat{P}_{i}^{G}}\right)^{-\sigma_{i}^{G}}$,

where the composite price of government purchases is:

$$
\hat{P}_{i}^{G}=\left[\delta_{i}^{G}\left(p_{i}\right)^{\left(1-\sigma_{i}^{G}\right)}+\left(1-\delta_{i}^{G}\right)\left(p_{i}^{*}\right)^{\left(1-\sigma_{i}^{G}\right)}\right]^{\frac{1}{1-\sigma_{i}^{G}}}
$$

\section{Investment demand:}

Investment behaviour is modelled as in the main text. The effect of changes in investment is to change the demand faced by the capital goods industry for products used by it as intermediate inputs. The capital goods sector employs no primary factors. It translates investment expenditure, ( $I$ in the main text but to avoid confusion with intermediates, below, it is here) $V$, into demands for goods and services:

$$
V_{i H j}=\frac{\delta_{i}^{V} a_{i}^{V}}{n_{i}}\left(\frac{V}{\hat{P}_{i}^{V}}\right)\left(\frac{\hat{P}_{i H}}{\hat{P}_{i}^{V}}\right)^{-\sigma_{i}^{V}}\left(\frac{p_{i H j}}{\hat{P}_{i H}}\right)^{-\eta_{i}^{V}},
$$

which simplifies to $V_{i}^{*}=\left(1-\delta_{i}^{V}\right) a_{i}^{V}\left(\frac{V}{\hat{P}_{i}^{V}}\right)\left(\frac{p_{i}^{*}}{\hat{P}_{i}^{V}}\right)^{-\sigma_{i}^{V}}$,

where the composite price of capital goods sector purchases is:

$$
\hat{P}_{i}^{K}=\left[\delta_{i}^{V}\left(p_{i}\right)^{\left(1-\sigma_{i}^{V}\right)}+\left(1-\delta_{i}^{V}\right)\left(p_{i}^{*}\right)^{\left(1-\sigma_{i}^{V}\right)}\right]^{\frac{1}{1-\sigma_{i}^{V}}} .
$$

This price is used as the average for all capital goods in the formulation of the rate of return on installed capital, which determines overall investment expenditure as in (4) and (5) in the main text. 


\section{Demand for inputs:}

This is derived from the input-output coefficients and gross industry output, $Q$, to be specified below. Demands for home-produced and imported varieties of the intermediate good $i$ are:

$$
I_{i}=\sum_{j=1}^{N} A_{i j} Q_{j}, \quad I_{i}^{*}=\sum_{j=1}^{N} A_{i j}^{*} Q_{j} \quad \forall i
$$

\section{Tax revenue:}

The government raises tax revenue from both direct and indirect taxation, the rates applied to each being exogenous and constant but the revenues earned then depend on levels of economic activity. The revenue raised from each source is expressed below.

Direct income tax revenue

$$
T_{Y}=\sum_{i=1}^{N} \tau_{K_{i}}\left(r K_{i}+\pi_{i}\right)+\tau_{U} w_{U} L_{U}+\tau_{S} w_{S} L_{S},
$$

where $K_{i}$ denotes total capital stock in industry $i, \pi_{i}$ denotes total pure profit in industry $i$ and the subscripts " $U$ " and " $S$ " denote unskilled and skilled labour (production workers and the combination of professionals and para-professionals as per the ILO classification of occupations). Note that the tax rate on capital income is not generic. This enables the capture of tax policies that discriminate between sectors.

\section{Consumption tax revenue}

$$
T_{C}=\sum_{i=1}^{N} \tau_{i}^{C} p_{i} D_{i}+\sum_{i=1}^{N} \tau_{i}^{C} p_{i}^{*} M_{i}
$$

Import tariff revenue

$$
T_{M}=\sum_{i=1}^{N} \tau_{i}^{M}\left(M_{i}+I_{i}^{*}\right) \frac{p_{i}^{w}}{e}
$$

Export tax revenue

$$
T_{X}=\sum_{i=1}^{N}\left(-S_{i}^{X}\right) p_{i} X_{i},
$$

where $s_{i}^{X}$ denotes the net power of the export subsidy rate.

Total tax revenue is then simply a sum of the individual components above.

\section{Pure or economic profits or losses:}

These are calculated as revenue derived from mark-ups over unit variable costs, less total fixed costs. For sector $i$ : 


$$
\pi_{i}=\left(p_{i}-v_{i}\right) Q_{i}-n_{i}\left(r f_{i}^{K}+w_{S} f_{i}^{L}\right) \quad \forall i,
$$

where $n_{i}$ is the number of firms, $f_{i}^{K}$ is the fixed capital requirement per firm and $f_{i}^{L}$ is the fixed skilled labour requirement per firm in sector $i$. Net profit in industry $i$ is therefore:

$$
\pi_{i}^{N}=\left[\left(p_{i}-v_{i}\right) Q_{i}-n_{i}\left(r f_{i}^{K}+w_{S} f_{i}^{L}\right)\right]\left(1-\tau_{i}^{K}\right) \quad \forall i
$$

\section{National income (GNP):}

This is the sum of payments to domestically owned factors of production with the home share of any net profits or losses made, the net income from indirect taxation and the net inflow from abroad, $B$, which represents the net income component of the current account and unrequited transfers.

(A1.27)

$$
Y=r K_{D}+\sum_{k=1}^{K} w_{k} L_{k}+\left(\frac{K_{D}}{K_{T}}\right) \sum_{i=1}^{N} \pi_{i}+\left(T-T_{Y}\right)+\frac{B}{e}+\left(1-\frac{K_{D}}{K_{T}}\right) \tau_{K}^{*}\left(r\left(K_{T}-K_{D}\right)+\sum_{i=1}^{N} \pi_{i}\right),
$$

where $T_{Y}$ is revenue from direct (income) tax. GDP, on the other hand, is a measure of the income from production in the domestic economy, so it excludes factor payments and other flows to and from abroad:

$$
G D P=r K_{T}+\sum_{k=1}^{K} w_{k} L_{k}+\sum_{i=1}^{N} \pi_{i}+\left(T-T_{Y}\right)
$$

\section{Total factor demands:}

The model has two capital market closures. In one (the "long run closure") physical capital is perfectly mobile abroad at the exogenous world interest rate $r$. In the other (the "short run closure"), physical capital stocks are fixed in each industry and industry rates of return are endogenous. Either way, physical capital is fully employed, with total demand having variable and fixed components:

$$
K_{T}=\sum_{i=1}^{N}\left(u_{i}^{K} Q_{i}+n_{i}^{D} f_{i}^{K}\right),
$$

where $f_{i}^{K}$ is the total fixed cost outlaid by industry $i$. Similarly, the demand for skilled labour also includes a variable and fixed component. It is:

$$
L_{S}=\sum_{i=1}^{N}\left(u_{S i}^{L} Q_{i}+n_{i}^{D} f_{i}^{L}\right)
$$

Finally, demand for all other variable factors (unskilled labour and mineral-energy resources) is:

$$
L_{j}=\sum_{i=1}^{N}\left(u_{j i}^{L} Q_{i}\right) \quad j=2, \ldots, F
$$

In the short run closure, employment of unskilled labour is endogenous, while either the real consumption or production wage is exogenous, so that unskilled labour can be unemployed. 


\section{A.2: Final Demand Elasticity with Price Interaction}

Here the final demand elasticity is derived to illustrate the method by which all the elasticity expressions of Appendix I (A1.1 - A1.4) are arrived at. From (A1.13) the demand equation for domestic variety $j$ of commodity $i$ is:

(A2.1) $d_{i H j}=\frac{\delta_{i}^{F} a_{i}^{F}}{n_{i}}\left(\frac{Y-T_{Y}}{\hat{P}_{i}^{F}}\right)\left(\frac{\hat{P}_{i H}}{\hat{P}_{i}^{F}}\right)^{-\sigma_{i}^{F}}\left(\frac{p_{i H j}}{\hat{P}_{i H}}\right)^{-\eta_{i}^{F}}$,

where the composite prices are the average price of generic product $i$ available on the home market from both home production and imports:

$$
\hat{P}_{i}^{F}=\left[\delta_{i}^{F}\left(p_{i H}\right)^{\left(1-\sigma_{i}^{F}\right)}+\left(1-\delta_{i}^{F}\right)\left(p_{i}^{*}\right)^{\left(1-\sigma_{i}^{F}\right)}\right]^{\frac{1}{1-\sigma_{i}^{F}}},
$$

and the average price of home varieties of product $i:{ }^{29}$

(A2.3) $\hat{P}_{i H}=\left[\frac{1}{n_{i}} \sum_{j=1}^{n_{i}}\left(p_{i H j}\right)^{\left(1-\eta_{i}^{F}\right)}\right]^{\frac{1}{1-\eta_{i}^{F}}}$.

Substitute (A2.2) and (A2.3) into (A2.1) and the full demand equation can be re-written as:

$$
\begin{aligned}
d_{i H j} & =\frac{\delta_{i}^{F} a_{i}^{F}}{n_{i}}\left(\frac{Y-T_{Y}}{\hat{P}_{i}^{F}}\right)\left(\frac{\hat{P}_{i H}}{\hat{P}_{i}^{F}}\right)^{-\sigma_{i}^{F}}\left(\frac{p_{i H j}}{\widehat{P}_{i H}}\right)^{-\eta_{i}^{F}} \\
& =\frac{\delta_{i}^{F} a_{i}^{F}}{n_{i}}\left(Y-T_{Y}\right)\left(\hat{P}_{i}^{F}\right)^{\sigma_{i}^{F}-1}\left(\hat{P}_{i H}\right)^{\left(\eta_{i}^{F}-\sigma_{i}^{F}\right)}\left(p_{i H j}\right)^{-\eta_{i}^{F}} \\
& =\frac{\delta_{i}^{F} a_{i}^{F}}{n_{i}}\left(Y-T_{Y}\right)\left[\delta_{i}^{F}\left(p_{i H}\right)^{\left(1-\sigma_{i}^{F}\right)}+\left(1-\delta_{i}^{F}\right)\left(p_{i}^{*}\right)^{\left(1-\sigma_{i}^{F}\right)}\right]^{-1}\left[\sum_{j=1}^{n_{i}} \frac{1}{n_{i}}\left(p_{i H j}\right)^{\left(1-\eta_{i}^{F}\right)}\right]^{\eta_{i}^{F}-\sigma_{i}^{F}}\left(p_{i H j}\right)^{-\eta_{i}^{F}}
\end{aligned}
$$

Differentiating with respect to $p_{i H j}$ gives:

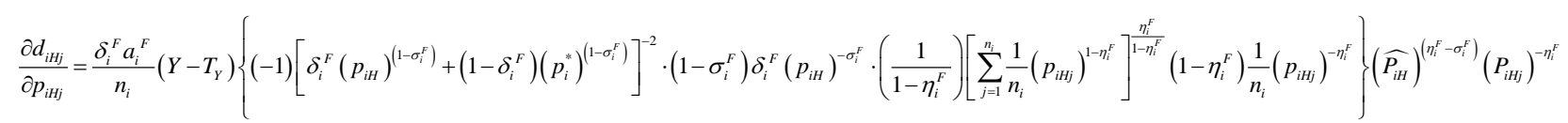

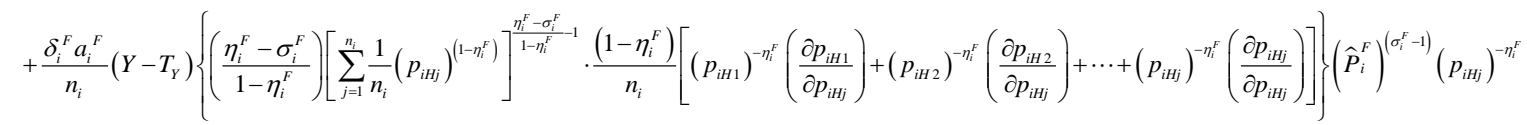

$$
\begin{aligned}
& +\frac{\delta_{i}^{F} a_{i}^{F}}{n_{i}}\left(Y-T_{Y}\right)\left\{\left(-\eta_{i}^{F}\right)\left(p_{i t H}\right)^{\left(-\eta_{i}^{F}-1\right)}\right\}\left(\hat{P}_{i}^{F}\right)^{\left(\sigma^{F}-1\right)}\left(\hat{P}_{i H}\right)^{\eta_{i}^{F}-\sigma_{i}^{F}}
\end{aligned}
$$

Noting that: $\frac{\partial p_{i H j}}{\partial p_{i H h}}=\left\{\begin{array}{ll}\mu_{i} & j \neq h \\ 1 & j=h\end{array}\right.$,

and noting further that $p_{i H j}=p_{i H h} \forall j \neq h$, because firms within an industry behave symmetrically, the expression can be written as:

\footnotetext{
${ }^{29}$ In equilibrium, because firms have identical technologies, these prices are equal, though this is not perceived by firms in setting their prices.
} 


$$
\begin{aligned}
& \frac{\partial d_{i H j}}{\partial p_{i H j}}=\frac{\delta_{i}^{F} a_{i}^{F}}{n_{i}}\left(Y-T_{Y}\right)\left(\sigma_{i}^{F}-1\right)\left(\hat{P}_{i}^{F}\right)^{2\left(\sigma_{i}^{F}-1\right)} \delta_{i}^{F} \cdot \frac{1}{n_{i}}\left(\hat{P}_{i H}\right)^{2\left(\eta_{i}^{F}-\sigma_{i}^{F}\right)}\left(p_{i H j}\right)^{-2 \eta_{i}^{F}} \\
& +\frac{\delta_{i}^{F} a_{i}^{F}}{n_{i}}\left(Y-T_{Y}\right)\left(\eta_{i}^{F}-\sigma_{i}^{F}\right)\left(\hat{P}_{i H}\right)^{\left(2 \eta_{i}^{F}-\sigma_{i}^{F}-1\right)} \frac{1}{n_{i}}\left(p_{i H j}\right)^{-2 \eta_{i}^{F}}\left(1+\left(n_{i}-1\right) \mu_{i}\right)\left(\hat{P}_{i}^{F}\right)^{\left(\sigma_{i}^{F}-1\right)} \\
& +\frac{\delta_{i}^{F} a_{i}^{F}}{n_{i}}\left(Y-T_{Y}\right)\left(-\eta_{i}^{F}\right)\left(p_{i H j}\right)^{\left(-\eta_{i}^{F}-1\right)}\left(\hat{P}_{i}^{F}\right)^{\left(\sigma_{i}^{F}-1\right)}\left(\hat{P}_{i H}\right)^{\eta_{i}^{F}-\sigma_{i}^{F}}
\end{aligned}
$$

This further simplifies to:

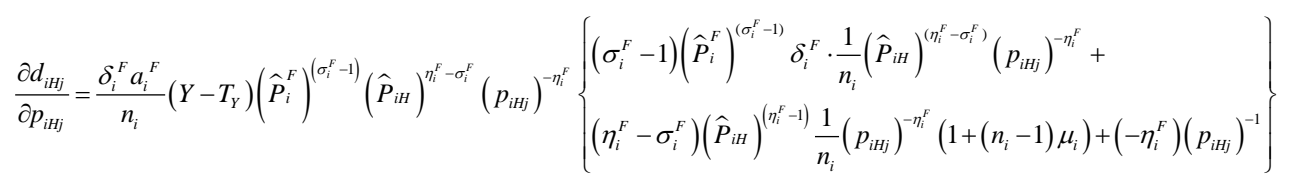

So that the elasticity of final demand is:

$$
\begin{aligned}
\frac{\partial d_{i H j}}{\partial p_{i H j}} \cdot \frac{p_{i H j}}{d_{i H j}} & \frac{\delta_{i}^{F} a_{i}^{F}}{n_{i}}\left(Y-T_{Y}\right)\left(\widehat{P_{i}^{F}}\right)^{\left(\sigma_{i}^{F}-1\right)}\left(\widehat{P}_{i H}\right)^{\eta_{i}^{F}-\sigma_{i}^{F}}\left(p_{i H j}\right)^{-\eta_{i}^{F}} \\
& \cdot\left\{\left(\sigma_{i}^{F}-1\right)\left(\widehat{P_{i}^{F}}\right)^{\left(\sigma_{i}^{F}-1\right)} \delta_{i}^{F} \cdot \frac{1}{n_{i}}\left(\widehat{P}_{i H}\right)^{\left(\eta_{i}^{F}-\sigma_{i}^{F}\right)}\left(p_{i H j}\right)^{-\eta_{i}^{F}}+\left(\eta_{i}^{F}-\sigma_{i}^{F}\right)\left(\widehat{P}_{i H}\right)^{\left(\eta_{i}^{F}-1\right)} \frac{1}{n_{i}}\left(p_{i H j}\right)^{-\eta_{i}^{F}}\left(1+\left(n_{i}-1\right) \mu_{i}\right)+\left(-\eta_{i}^{F}\right)\left(p_{i H j}\right)^{-1}\right\} \\
& \cdot \frac{p_{i H j}}{\frac{\delta_{i}^{F} a_{i}^{F}}{n_{i}}\left(Y-T_{Y}\right)\left(\widehat{P}_{i}^{F}\right)^{\left(\sigma_{i}^{F}-1\right)}\left(\widehat{P}_{i H}\right)^{\eta_{i}^{F}-\sigma_{i}^{F}}\left(p_{i H j}\right)^{-\eta_{i}^{F}}}
\end{aligned}
$$

On the symmetry assumption this simplifies to:

$$
\varepsilon_{i}^{F}=-\eta_{i}^{F}+\frac{1}{n_{i}}\left(\frac{p_{i H j}}{\widehat{P}_{i H}}\right)^{1-\eta_{i}^{F}}\left\{\left(\sigma_{i}^{F}-1\right) \delta_{i}^{F}\left(\frac{\widehat{P}_{i H}}{\hat{P}_{i}^{F}}\right)^{\left(1-\sigma_{i}^{F}\right)}+\left(\eta_{i}^{F}-\sigma_{i}^{F}\right)\left(1+\left(n_{i}-1\right) \mu_{i}\right)\right\}
$$

\section{Appendix 3: The Database and the Oligopoly Calibration}

The basic flow database is from the GTAP VII data for 2007. It supplies most of the elements of the social accounting matrix. It combines detailed bilateral trade, transport and protection data characterizing economic linkages among regions, together with individual country national accounts, government accounts, balance of payments data and input-output tables which enable the quantification of inter-sectoral flows within regions. The first step toward completing the database is to extract the indirect tax components from trade flows and consumption payments. This enables the completion of the government revenue row of the matrix.

The second is to allocate profits after tax, depreciation and "abnormals" between retained earnings (corporate saving) and dividends. This requires the first call on the Morningstar data on listed firms. Transfers between government and households, direct tax and household saving, along with elements of the balance of payments, are then acquired to enable the completion of rows and columns associated with household and government incomes and outlays, as well as column entries for saving. Further issues associated with the flow database are discussed in Section 3 of the main text. 
Turning to the industrial organisation components of the database, no complete set of data on the structure and conduct of Australia's agricultural, manufacturing and mining sectors is publicly available let alone of its service industries. Some relevant data is available piecemeal, for individual sectors or industries, though this is occasionally at too fine a level of aggregation for an illustrative economy-wide study such as this. It has therefore been necessary to extrapolate patterns to some sectors and to make crude assumptions about others. To clarify the assumptions made, this appendix offers an expansion of the summary given in Section 3 of the text.

First, estimates of pure (over-market) profits are required as shares of revenue in each industry. This is needed to finalise the flow database but also to calibrate industry competitive structure. For these data on the profitability of listed public firms from the Morningstar Aspect-Huntley Financial Analysis Database is used. ${ }^{30}$ For this comparative static analysis, depreciation and "abnormals" are considered firm costs and so deducted from gross profits at the outset. After tax accounting profit rates imply rates of return that are compared with borrowing rates on corporate debt (as implied by the corresponding data on debt and debt service) to obtain measures of pure profits. ${ }^{31}$

Second, rough estimates of strategically interacting firm numbers in each industry and their corresponding conjectural variations parameters are required. It is not sufficient simply to record the number of establishments in each industry, however. Unless industries are subdivided finely, considerable diversity of firm size and product is embodied in each. Indeed, within a particular industry classification, many firms supply intermediate inputs to other firms in the same classification. Prices of the products that emerge from a particular industry are very likely determined by a small proportion of the firms within it. For estimates of "strategically interacting" firm numbers in each industry and their corresponding conjectural variations parameters, the Morningstar database is again used to examine industry structure in each sector, focussing on the numbers of firms supplying more than 60 per cent of industry capital (market capitalisation plus net debt). The results of this analysis are displayed in Table A3.1. In the end the values for the "effective" number of firms and the conjectural variations parameter in each sector are judgemental, taking into account the numbers of missing private firms and farms and the extent of regulatory surveillance limiting the full exploitation of oligopoly power.

Third, to complete the formulation of industry demand elasticities, elasticities of substitution between home product varieties and between generic home and foreign products are required for each sector. These are drawn from the estimation literature. ${ }^{32}$ Initial industry demand elasticities are then calculated for each source of demand (final, investment, intermediate, government and export), via the equations in Appendices 1 and 2. Initial shares of the demand facing each industry are then drawn from the database and shown in Table A3.2. These enable the calculation of weighted average demand elasticities for each industry. Mark-up ratios are then deduced from these, fixing average variable cost in each sector, via equation (8). The initial equilibrium average elasticities and mark-up ratios for each sector are given in Table 4 of the main text. Note that the elasticities appear large in magnitude at first glance. This is because

\footnotetext{
${ }^{30}$ The database is formally the Aspect Financial Analysis Database. It is supplied by Aspect-Huntley, and the copyright is held by Huntleys' Investment Information Pty Ltd (HII) (a wholly owned subsidiary of Morningstar, Inc): http://www.aspectfinancial.com.au/af/finhome?xtm-licensee=finanalysis.for.

${ }^{31}$ This set of approximations is obviously precarious. It considers only listed firms, thus ignoring most of the farming community in agriculture and the small and family businesses in the services sector, not to mention large private firms in all sectors and government-owned service firms.

${ }^{32}$ Summaries of this literature are offered by Dimaranan and McDougall (2002) and at http://www.gtap. purdue.edu/databases/..
} 
they do not represent the slopes of industry demand curves for generic goods. Rather, they are the elasticities faced by suppliers of individual varieties and are made larger by inter-varietal substitution.

This completes the demand side calibration. It enables us to turn to the calibration of the supply side, where we begin by using the mark-up ratios to deduce the initial level of average variable cost in each sector. The proportion pure profits make up of total turnover is deducted from the mark-up to arrive at fixed cost shares of total turnover. ${ }^{33}$ Total recurrent fixed cost in each sector then follows. The results of this calibration are summarised in the first three columns of Table 5 in the main text. It is now possible to obtain a sense of the scale of production. ${ }^{34}$ Under our assumption of Cobb-Douglas technology in variable factor use, combined with recurrent fixed costs, if industries could expand indefinitely without changing unit factor rewards (the partial equilibrium assumption that is relaxed here), average fixed cost would approach average variable cost asymptotically from above. Following Harris and Cox (1983) we choose an arbitrary minimum efficient scale (MES) product volume at the point where average fixed cost would decline to a twentieth of average variable cost. The implied scale parameters are displayed in the final column of Table 5 in the main text. They confirm expectations that fixed costs are most prominent in electricity, gas, water, telecommunications and transport services, due to fixed physical infrastructure and network maintenance costs. The results also suggest, plausibly, that the sectors closest to their minimum efficient scale are agriculture, mining, finance and "other services".

\footnotetext{
${ }^{33}$ Fixed costs take the form of both physical and human capital costs using the rule of thumb (based on estimates by Harris and Cox, 1983) that physical capital has a fixed cost share of 5/6.

${ }^{34}$ The actual calibration process is more complex than this because the elasticities of intermediate demand depend on intermediate cost shares, which depend on the variable cost share. It is therefore necessary to calibrate iteratively for consistency of elasticities and shares.
} 


\section{Table A3.1: Effective Firms and Conjectural Variations}

\begin{tabular}{lcccc}
\hline & $\begin{array}{l}\text { Listed firms with } \\
60 \% \text { industry } \\
\text { capital }\end{array}$ & $\begin{array}{l}\text { Listed firms with } \\
80 \% \text { industry } \\
\text { capital }\end{array}$ & $\begin{array}{l}\text { Effective } \\
\text { firm number }\end{array}$ & $\begin{array}{l}\text { Conjectural } \\
\text { Variations: 0-1 }^{\mathrm{b}}\end{array}$ \\
Agriculture & 3 & 6 & 100 & 0.1 \\
Manufacturing & 4 & 19 & 20 & 0.2 \\
Mining \& energy & 5 & 10 & 10 & 0.4 \\
Electricity & 2 & 5 & 6 & 0.6 \\
Water & - & - & 6 & 0.3 \\
Gas Distribution & 2 & 2 & 2 & 0.5 \\
Telecommunications & 2 & 2 & 4 & 0.6 \\
Finance & 8 & 19 & 10 & 0.5 \\
Transport & 4 & 5 & 10 & 0.5 \\
Other Services & 5 & 20 & 100 & 0.2 \\
\hline
\end{tabular}

a This index represents the "effective" number of strategically interacting firms in each sector. Firm numbers exceeding 100 have negligible effect on pricing. It is borne in mind that large numbers of farms and private firms are omitted from the data.

b The conjectural variations parameter ranges between zero (non-collusive oligopoly) and unity (cartel). The numbers chosen reflect industry concentration and the extent of existing regulatory surveillance.

Sources: Morningstar Financial Analysis Database of listed Australian firms.

\section{Table A3.2: Demand Shares by Source ${ }^{\mathrm{a}}$}

\begin{tabular}{lccccc}
\hline Per cent & Final & Government & Investment & Intermediate & Export \\
Agriculture & 14.9 & 0.6 & 2.1 & 58.6 & 23.9 \\
Manufacturing & 20.1 & 0.4 & 7.7 & 47.8 & 24.1 \\
Mining \& energy & 6.6 & 0.0 & 0.9 & 53.8 & 38.8 \\
Electricity & 24.3 & 0.0 & 0.0 & 75.7 & 0.0 \\
Water & 38.4 & 8.6 & 0.0 & 51.4 & 1.6 \\
Gas Distribution & 5.8 & 0.0 & 0.0 & 86.5 & 7.7 \\
Telecommunications & 29.7 & 0.2 & 0.0 & 67.5 & 2.7 \\
Finance & 33.0 & 0.2 & 0.0 & 63.9 & 3.0 \\
Transport & 42.5 & 2.4 & 6.7 & 43.3 & 5.2 \\
Other Services & 18.6 & 18.9 & 20.5 & 40.1 & 1.9 \\
& & & & & \\
Total demand & $\mathbf{2 3 . 1}$ & $\mathbf{8 . 9}$ & $\mathbf{1 1 . 7}$ & $\mathbf{4 6 . 3}$ & $\mathbf{1 0 . 0}$ \\
\hline
\end{tabular}

a Shares sum to 100 across.

Source: Model database (social accounting matrix), based on the Australian component of the GTAP Database for 2007. 
Editor, UWA Economics Discussion Papers:

Ernst Juerg Weber

Business School - Economics

University of Western Australia

35 Sterling Hwy

Crawley WA 6009

Australia

Email: ecoadmin@biz.uwa.edu.au

The Economics Discussion Papers are available at:

1980 - 2002: http://ecompapers.biz.uwa.edu.au/paper/PDF\%20of\%20Discussion\%20Papers/

Since 2001: http://ideas.repec.org/s/uwa/wpaper1.html

Since 2004: http://www.business.uwa.edu.au/school/disciplines/economics

\section{ECONOMICS DISCUSSION PAPERS}

2012

\begin{tabular}{|c|c|c|}
\hline $\begin{array}{l}\text { DP } \\
\text { NUMBER }\end{array}$ & AUTHORS & TITLE \\
\hline 12.01 & $\begin{array}{l}\text { Clements, K.W., Gao, G., and } \\
\text { Simpson, T. }\end{array}$ & $\begin{array}{l}\text { DISPARITIES IN INCOMES AND PRICES } \\
\text { INTERNATIONALLY }\end{array}$ \\
\hline 12.02 & Tyers, R. & $\begin{array}{l}\text { THE RISE AND ROBUSTNESS OF ECONOMIC FREEDOM } \\
\text { IN CHINA }\end{array}$ \\
\hline 12.03 & Golley, J. and Tyers, R. & $\begin{array}{l}\text { DEMOGRAPHIC DIVIDENDS, DEPENDENCIES AND } \\
\text { ECONOMIC GROWTH IN CHINA AND INDIA }\end{array}$ \\
\hline 12.04 & Tyers, R. & LOOKING INWARD FOR GROWTH \\
\hline 12.05 & Knight, K. and McLure, M. & THE ELUSIVE ARTHUR PIGOU \\
\hline 12.06 & McLure, M. & $\begin{array}{l}\text { ONE HUNDRED YEARS FROM TODAY: A. C. PIGOU'S } \\
\text { WEALTH AND WELFARE }\end{array}$ \\
\hline 12.07 & Khuu, A. and Weber, E.J. & HOW AUSTRALIAN FARMERS DEAL WITH RISK \\
\hline 12.08 & Chen, M. and Clements, K.W. & PATTERNS IN WORLD METALS PRICES \\
\hline 12.09 & Clements, K.W. & UWA ECONOMICS HONOURS \\
\hline 12.10 & Golley, J. and Tyers, R. & $\begin{array}{l}\text { CHINA'S GENDER IMBALANCE AND ITS ECONOMIC } \\
\text { PERFORMANCE }\end{array}$ \\
\hline 12.11 & Weber, E.J. & $\begin{array}{l}\text { AUSTRALIAN FISCAL POLICY IN THE AFTERMATH OF } \\
\text { THE GLOBAL FINANCIAL CRISIS }\end{array}$ \\
\hline 12.12 & Hartley, P.R. and Medlock III, K.B. & $\begin{array}{l}\text { CHANGES IN THE OPERATIONAL EFFICIENCY OF } \\
\text { NATIONAL OIL COMPANIES }\end{array}$ \\
\hline 12.13 & Li, L. & $\begin{array}{l}\text { HOW MUCH ARE RESOURCE PROJECTS WORTH? A } \\
\text { CAPITAL MARKET PERSPECTIVE }\end{array}$ \\
\hline 12.14 & Chen, A. and Groenewold, N. & $\begin{array}{l}\text { THE REGIONAL ECONOMIC EFFECTS OF A } \\
\text { REDUCTION IN CARBON EMISSIONS AND AN } \\
\text { EVALUATION OF OFFSETTING POLICIES IN CHINA }\end{array}$ \\
\hline 12.15 & Collins, J., Baer, B. and Weber, E.J. & $\begin{array}{l}\text { SEXUAL SELECTION, CONSPICUOUS CONSUMPTION } \\
\text { AND ECONOMIC GROWTH }\end{array}$ \\
\hline
\end{tabular}




\begin{tabular}{|c|c|c|}
\hline \multicolumn{3}{|c|}{$\begin{array}{l}\text { ECONOMICS DISCUSSION PAPERS } \\
2012\end{array}$} \\
\hline $\begin{array}{l}\text { DP } \\
\text { NUMBER }\end{array}$ & AUTHORS & TITLE \\
\hline 12.16 & Wu, Y. & TRENDS AND PROSPECTS IN CHINA'S R\&D SECTOR \\
\hline 12.17 & Cheong, T.S. and Wu, Y. & $\begin{array}{l}\text { INTRA-PROVINCIAL INEQUALITY IN CHINA: AN } \\
\text { ANALYSIS OF COUNTY-LEVEL DATA }\end{array}$ \\
\hline 12.18 & Cheong, T.S. & THE PATTERNS OF REGIONAL INEQUALITY IN CHINA \\
\hline 12.19 & Wu, Y. & $\begin{array}{l}\text { ELECTRICITY MARKET INTEGRATION: GLOBAL } \\
\text { TRENDS AND IMPLICATIONS FOR THE EAS REGION }\end{array}$ \\
\hline 12.20 & Knight, K. & $\begin{array}{l}\text { EXEGESIS OF DIGITAL TEXT FROM THE HISTORY OF } \\
\text { ECONOMIC THOUGHT: A COMPARATIVE } \\
\text { EXPLORATORY TEST }\end{array}$ \\
\hline 12.21 & Chatterjee, I. & $\begin{array}{l}\text { COSTLY REPORTING, EX-POST MONITORING, AND } \\
\text { COMMERCIAL PIRACY: A GAME THEORETIC } \\
\text { ANALYSIS }\end{array}$ \\
\hline 12.22 & Pen, S.E. & QUALITY-CONSTANT ILLICIT DRUG PRICES \\
\hline 12.23 & Cheong, T.S. and Wu, Y. & $\begin{array}{l}\text { REGIONAL DISPARITY, TRANSITIONAL DYNAMICS } \\
\text { AND CONVERGENCE IN CHINA }\end{array}$ \\
\hline 12.24 & Ezzati, P. & $\begin{array}{l}\text { FINANCIAL MARKETS INTEGRATION OF IRAN } \\
\text { WITHIN THE MIDDLE EAST AND WITH THE REST OF } \\
\text { THE WORLD }\end{array}$ \\
\hline 12.25 & Kwan, F., Wu, Y. and Zhuo, S. & $\begin{array}{l}\text { RE-EXAMINATION OF THE SURPLUS AGRICULTURAL } \\
\text { LABOUR IN CHINA }\end{array}$ \\
\hline 12.26 & Wu, Y. & R\&D BEHAVIOUR IN CHINESE FIRMS \\
\hline 12.27 & Tang, S.H.K. and Yung, L.C.W. & $\begin{array}{l}\text { MAIDS OR MENTORS? THE EFFECTS OF LIVE-IN } \\
\text { FOREIGN DOMESTIC WORKERS ON SCHOOL } \\
\text { CHILDREN'S EDUCATIONAL ACHIEVEMENT IN HONG } \\
\text { KONG }\end{array}$ \\
\hline 12.28 & Groenewold, N. & $\begin{array}{l}\text { AUSTRALIA AND THE GFC: SAVED BY ASTUTE } \\
\text { FISCAL POLICY? }\end{array}$ \\
\hline
\end{tabular}




\section{ECONOMICS DISCUSSION PAPERS}

2013

\begin{tabular}{|c|c|c|}
\hline $\begin{array}{l}\text { DP } \\
\text { NUMBER }\end{array}$ & AUTHORS & TITLE \\
\hline 13.01 & $\begin{array}{l}\text { Chen, M., Clements, K.W. and } \\
\text { Gao, G. }\end{array}$ & THREE FACTS ABOUT WORLD METAL PRICES \\
\hline 13.02 & Collins, J. and Richards, O. & $\begin{array}{l}\text { EVOLUTION, FERTILITY AND THE AGEING } \\
\text { POPULATION }\end{array}$ \\
\hline 13.03 & $\begin{array}{l}\text { Clements, K., Genberg, H., } \\
\text { Harberger, A., Lothian, J., } \\
\text { Mundell, R., Sonnenschein, H. and } \\
\text { Tolley, G. }\end{array}$ & LARRY SJAASTAD, 1934-2012 \\
\hline 13.04 & Robitaille, M.C. and Chatterjee, I. & MOTHERS-IN-LAW AND SON PREFERENCE IN INDIA \\
\hline 13.05 & Clements, K.W. and Izan, I.H.Y. & $\begin{array}{l}\text { REPORT ON THE } 25^{\mathrm{TH}} \text { PHD CONFERENCE IN } \\
\text { ECONOMICS AND BUSINESS }\end{array}$ \\
\hline 13.06 & Walker, A. and Tyers, R. & QUANTIFYING AUSTRALIA’S “THREE SPEED” BOOM \\
\hline 13.07 & Yu, F. and Wu, Y. & PATENT EXAMINATION AND DISGUISED PROTECTION \\
\hline 13.08 & $\mathrm{Yu}, \mathrm{F}$. and $\mathrm{Wu}, \mathrm{Y}$. & $\begin{array}{l}\text { PATENT CITATIONS AND KNOWLEDGE SPILLOVERS: } \\
\text { AN ANALYSIS OF CHINESE PATENTS REGISTER IN } \\
\text { THE US }\end{array}$ \\
\hline 13.09 & Chatterjee, I. and Saha, B. & BARGAINING DELEGATION IN MONOPOLY \\
\hline 13.10 & Cheong, T.S. and Wu, Y. & $\begin{array}{l}\text { GLOBALIZATION AND REGIONAL INEQUALITY IN } \\
\text { CHINA }\end{array}$ \\
\hline 13.11 & Cheong, T.S. and Wu, Y. & INEQUALITY AND CRIME RATES IN CHINA \\
\hline 13.12 & Robertson, P.E. and Ye, L. & ON THE EXISTENCE OF A MIDDLE INCOME TRAP \\
\hline 13.13 & Robertson, P.E. & THE GLOBAL IMPACT OF CHINA’S GROWTH \\
\hline 13.14 & $\begin{array}{l}\text { Hanaki, N., Jacquemet, N., } \\
\text { Luchini, S., and Zylbersztejn, A. }\end{array}$ & $\begin{array}{l}\text { BOUNDED RATIONALITY AND STRATEGIC } \\
\text { UNCERTAINTY IN A SIMPLE DOMINANCE SOLVABLE } \\
\text { GAME }\end{array}$ \\
\hline 13.15 & $\begin{array}{l}\text { Okatch, Z., Siddique, A. and } \\
\text { Rammohan, A. }\end{array}$ & $\begin{array}{l}\text { DETERMINANTS OF INCOME INEQUALITY IN } \\
\text { BOTSWANA }\end{array}$ \\
\hline 13.16 & Clements, K.W. and Gao, G. & $\begin{array}{l}\text { A MULTI-MARKET APPROACH TO MEASURING THE } \\
\text { CYCLE }\end{array}$ \\
\hline 13.17 & Chatterjee, I. and Ray, R. & $\begin{array}{l}\text { THE ROLE OF INSTITUTIONS IN THE INCIDENCE OF } \\
\text { CRIME AND CORRUPTION }\end{array}$ \\
\hline 13.18 & Fu, D. and $\mathrm{Wu}, \mathrm{Y}$. & $\begin{array}{l}\text { EXPORT SURVIVAL PATTERN AND DETERMINANTS } \\
\text { OF CHINESE MANUFACTURING FIRMS }\end{array}$ \\
\hline 13.19 & Shi, X., Wu, Y. and Zhao, D. & $\begin{array}{l}\text { KNOWLEDGE INTENSIVE BUSINESS SERVICES AND } \\
\text { THEIR IMPACT ON INNOVATION IN CHINA }\end{array}$ \\
\hline 13.20 & $\begin{array}{l}\text { Tyers, R., Zhang, Y. and } \\
\text { Cheong, T.S. }\end{array}$ & $\begin{array}{l}\text { CHINA’S SAVING AND GLOBAL ECONOMIC } \\
\text { PERFORMANCE }\end{array}$ \\
\hline 13.21 & Collins, J., Baer, B. and Weber, E.J. & $\begin{array}{l}\text { POPULATION, TECHNOLOGICAL PROGRESS AND THE } \\
\text { EVOLUTION OF INNOVATIVE POTENTIAL }\end{array}$ \\
\hline 13.22 & Hartley, P.R. & THE FUTURE OF LONG-TERM LNG CONTRACTS \\
\hline 13.23 & Tyers, R. & $\begin{array}{l}\text { A SIMPLE MODEL TO STUDY GLOBAL } \\
\text { MACROECONOMIC INTERDEPENDENCE }\end{array}$ \\
\hline
\end{tabular}




\begin{tabular}{|c|c|c|}
\hline \multicolumn{3}{|c|}{$\begin{array}{c}\text { ECONOMICS DISCUSSION PAPERS } \\
2013\end{array}$} \\
\hline $\begin{array}{l}\text { DP } \\
\text { NUMBER }\end{array}$ & AUTHORS & TITLE \\
\hline 13.24 & McLure, M. & $\begin{array}{l}\text { REFLECTIONS ON THE QUANTITY THEORY: PIGOU IN } \\
1917 \text { AND PARETO IN 1920-21 }\end{array}$ \\
\hline 13.25 & Chen, A. and Groenewold, N. & $\begin{array}{l}\text { REGIONAL EFFECTS OF AN EMISSIONS-REDUCTION } \\
\text { POLICY IN CHINA: THE IMPORTANCE OF THE } \\
\text { GOVERNMENT FINANCING METHOD }\end{array}$ \\
\hline 13.26 & Siddique, M.A.B. & $\begin{array}{l}\text { TRADE RELATIONS BETWEEN AUSTRALIA AND } \\
\text { THAILAND: } 1990 \text { TO } 2011\end{array}$ \\
\hline 13.27 & Li, B. and Zhang, J. & $\begin{array}{l}\text { GOVERNMENT DEBT IN AN INTERGENERATIONAL } \\
\text { MODEL OF ECONOMIC GROWTH, ENDOGENOUS } \\
\text { FERTILITY, AND ELASTIC LABOR WITH AN } \\
\text { APPLICATION TO JAPAN }\end{array}$ \\
\hline 13.28 & Robitaille, M. and Chatterjee, I. & $\begin{array}{l}\text { SEX-SELECTIVE ABORTIONS AND INFANT } \\
\text { MORTALITY IN INDIA: THE ROLE OF PARENTS' } \\
\text { STATED SON PREFERENCE }\end{array}$ \\
\hline 13.29 & Ezzati, P. & $\begin{array}{l}\text { ANALYSIS OF VOLATILITY SPILLOVER EFFECTS: } \\
\text { TWO-STAGE PROCEDURE BASED ON A MODIFIED } \\
\text { GARCH-M }\end{array}$ \\
\hline 13.30 & Robertson, P. E. & $\begin{array}{l}\text { DOES A FREE MARKET ECONOMY MAKE AUSTRALIA } \\
\text { MORE OR LESS SECURE IN A GLOBALISED WORLD? }\end{array}$ \\
\hline 13.31 & $\begin{array}{l}\text { Das, S., Ghate, C. and } \\
\text { Robertson, P. E. }\end{array}$ & $\begin{array}{l}\text { REMOTENESS AND UNBALANCED GROWTH: } \\
\text { UNDERSTANDING DIVERGENCE ACROSS INDIAN } \\
\text { DISTRICTS }\end{array}$ \\
\hline 13.32 & Robertson, P.E. and Sin, A. & $\begin{array}{l}\text { MEASURING HARD POWER: CHINA'S ECONOMIC } \\
\text { GROWTH AND MILITARY CAPACITY }\end{array}$ \\
\hline 13.33 & Wu, Y. & $\begin{array}{l}\text { TRENDS AND PROSPECTS FOR THE RENEWABLE } \\
\text { ENERGY SECTOR IN THE EAS REGION }\end{array}$ \\
\hline 13.34 & $\begin{array}{l}\text { Yang, S., Zhao, D., Wu, Y. and } \\
\text { Fan, J. }\end{array}$ & $\begin{array}{l}\text { REGIONAL VARIATION IN CARBON EMISSION AND } \\
\text { ITS DRIVING FORCES IN CHINA: AN INDEX } \\
\text { DECOMPOSITION ANALYSIS }\end{array}$ \\
\hline
\end{tabular}




\begin{tabular}{|c|c|c|}
\hline \multicolumn{3}{|c|}{$\begin{array}{l}\text { ECONOMICS DISCUSSION PAPERS } \\
2014\end{array}$} \\
\hline $\begin{array}{l}\text { DP } \\
\text { NUMBER }\end{array}$ & AUTHORS & TITLE \\
\hline 14.01 & $\begin{array}{l}\text { Boediono, Vice President of the Republic } \\
\text { of Indonesia }\end{array}$ & $\begin{array}{l}\text { THE CHALLENGES OF POLICY MAKING IN A } \\
\text { YOUNG DEMOCRACY: THE CASE OF INDONESIA } \\
\text { (52ND SHANN MEMORIAL LECTURE, 2013) }\end{array}$ \\
\hline 14.02 & Metaxas, P.E. and Weber, E.J. & $\begin{array}{l}\text { AN AUSTRALIAN CONTRIBUTION TO } \\
\text { INTERNATIONAL TRADE THEORY: THE } \\
\text { DEPENDENT ECONOMY MODEL }\end{array}$ \\
\hline 14.03 & Fan, J., Zhao, D., Wu, Y. and Wei, J. & $\begin{array}{l}\text { CARBON PRICING AND ELECTRICITY MARKET } \\
\text { REFORMS IN CHINA }\end{array}$ \\
\hline 14.04 & McLure, M. & $\begin{array}{l}\text { A.C. PIGOU'S MEMBERSHIP OF THE } \\
\text { 'CHAMBERLAIN-BRADBURY' COMMITTEE. } \\
\text { PART I: THE HISTORICAL CONTEXT }\end{array}$ \\
\hline 14.05 & McLure, M. & $\begin{array}{l}\text { A.C. PIGOU’S MEMBERSHIP OF THE } \\
\text { 'CHAMBERLAIN-BRADBURY’ COMMITTEE. } \\
\text { PART II: ‘TRANSITIONAL’AND ‘ONGOING’ ISSUES }\end{array}$ \\
\hline 14.06 & King, J.E. and McLure, M. & HISTORY OF THE CONCEPT OF VALUE \\
\hline 14.07 & Williams, A. & $\begin{array}{l}\text { A GLOBAL INDEX OF INFORMATION AND } \\
\text { POLITICAL TRANSPARENCY }\end{array}$ \\
\hline 14.08 & Knight, K. & $\begin{array}{l}\text { A.C. PIGOU'S THE THEORY OF UNEMPLOYMENT } \\
\text { AND ITS CORRIGENDA: THE LETTERS OF } \\
\text { MAURICE ALLEN, ARTHUR L. BOWLEY, RICHARD } \\
\text { KAHN AND DENNIS ROBERTSON }\end{array}$ \\
\hline 14.09 & Cheong, T.S. and Wu, Y. & $\begin{array}{l}\text { THE IMPACTS OF STRUCTURAL RANSFORMATION } \\
\text { AND INDUSTRIAL UPGRADING ON REGIONAL } \\
\text { INEQUALITY IN CHINA }\end{array}$ \\
\hline 14.10 & $\begin{array}{l}\text { Chowdhury, M.H., Dewan, M.N.A., } \\
\text { Quaddus, M., Naude, M. and } \\
\text { Siddique, A. }\end{array}$ & $\begin{array}{l}\text { GENDER EQUALITY AND SUSTAINABLE } \\
\text { DEVELOPMENT WITH A FOCUS ON THE COASTAL } \\
\text { FISHING COMMUNITY OF BANGLADESH }\end{array}$ \\
\hline 14.11 & Bon, J. & $\begin{array}{l}\text { UWA DISCUSSION PAPERS IN ECONOMICS: THE } \\
\text { FIRST } 750\end{array}$ \\
\hline 14.12 & Finlay, K. and Magnusson, L.M. & $\begin{array}{l}\text { BOOTSTRAP METHODS FOR INFERENCE WITH } \\
\text { CLUSTER-SAMPLE IV MODELS }\end{array}$ \\
\hline 14.13 & Chen, A. and Groenewold, N. & $\begin{array}{l}\text { THE EFFECTS OF MACROECONOMIC SHOCKS ON } \\
\text { THE DISTRIBUTION OF PROVINCIAL OUTPUT IN } \\
\text { CHINA: ESTIMATES FROM A RESTRICTED VAR } \\
\text { MODEL }\end{array}$ \\
\hline 14.14 & Hartley, P.R. and Medlock III, K.B. & $\begin{array}{l}\text { THE VALLEY OF DEATH FOR NEW ENERGY } \\
\text { TECHNOLOGIES }\end{array}$ \\
\hline 14.15 & $\begin{array}{l}\text { Hartley, P.R., Medlock III, K.B., } \\
\text { Temzelides, T. and Zhang, X. }\end{array}$ & $\begin{array}{l}\text { LOCAL EMPLOYMENT IMPACT FROM COMPETING } \\
\text { ENERGY SOURCES: SHALE GAS VERSUS WIND } \\
\text { GENERATION IN TEXAS }\end{array}$ \\
\hline 14.16 & Tyers, R. and Zhang, Y. & $\begin{array}{l}\text { SHORT RUN EFFECTS OF THE ECONOMIC REFORM } \\
\text { AGENDA }\end{array}$ \\
\hline 14.17 & Clements, K.W., Si, J. and Simpson, T. & UNDERSTANDING NEW RESOURCE PROJECTS \\
\hline 14.18 & Tyers, R. & $\begin{array}{l}\text { SERVICE OLIGOPOLIES AND AUSTRALIA’S } \\
\text { ECONOMY-WIDE PERFORMANCE }\end{array}$ \\
\hline 14.19 & Tyers, R. and Zhang, Y. & $\begin{array}{l}\text { REAL EXCHANGE RATE DETERMINATION AND } \\
\text { THE CHINA PUZZLE }\end{array}$ \\
\hline
\end{tabular}




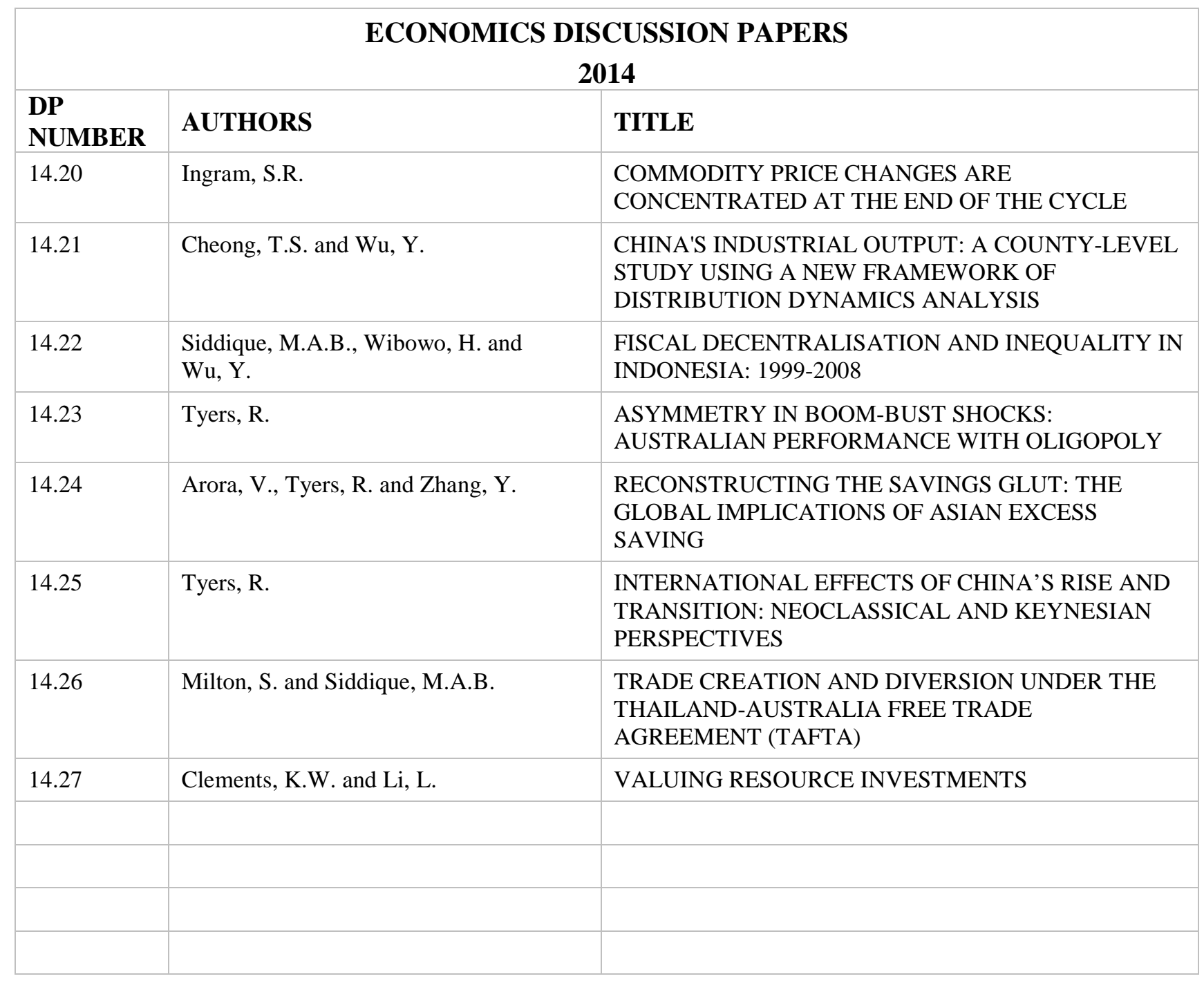

